\title{
دراسة نفسية لدى فاقدات وغير فاقدات الأم
}

\author{
اعداد \\ هبه الله محمد عوض \\ باحثة نفسية
}

مجلة بحوث التربية النوعية ـ جامعة المنصورة

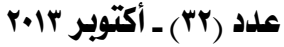




\section{دراسة نفسية لدى فاقدات وغير فاقدات الأم}

إعداد

* هبهالله محمد عوض

أولاً: مششكلة الدراستة:

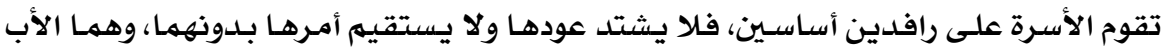

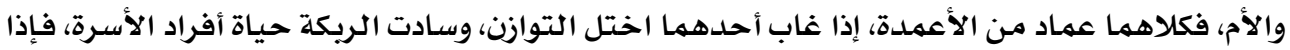

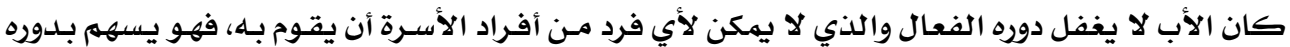

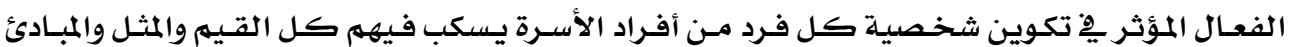

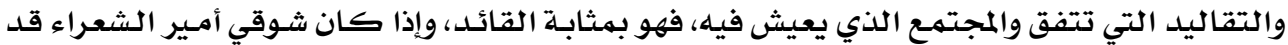

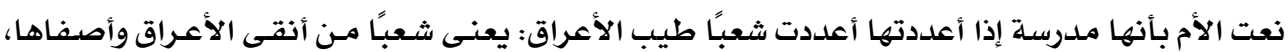

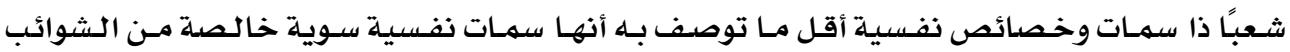

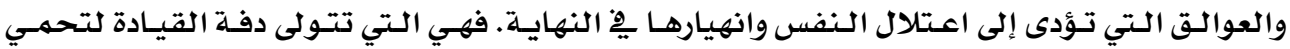

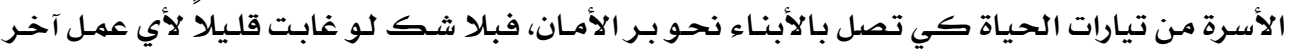

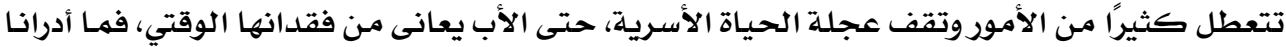

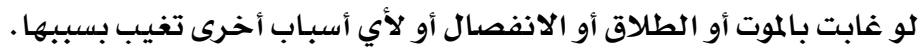

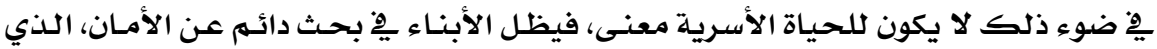

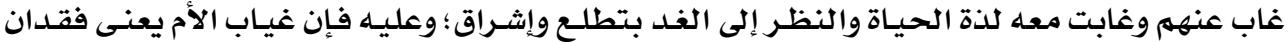

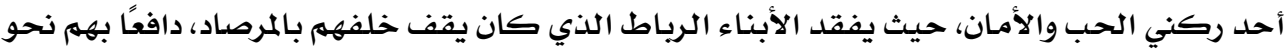

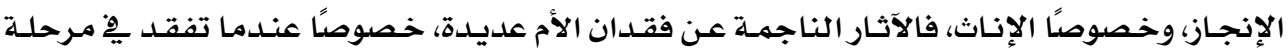

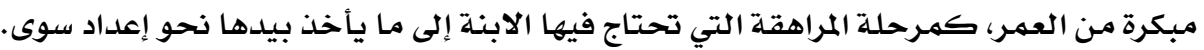

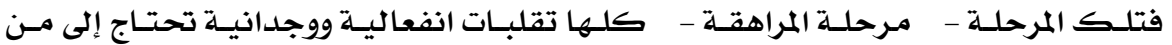

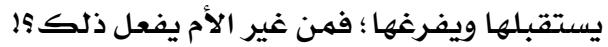

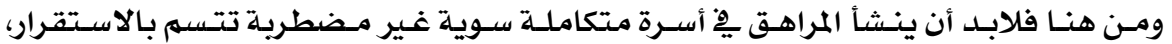

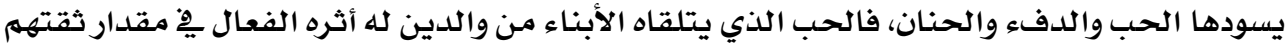

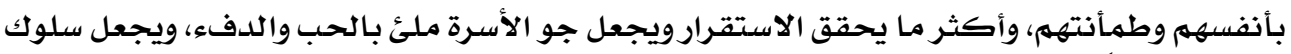

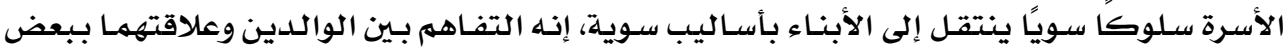

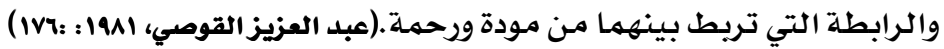

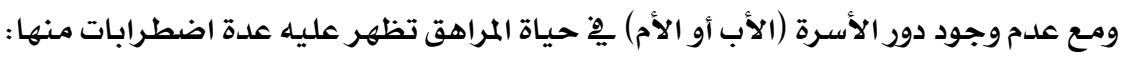


1) مظاهر يأس، وكأنه ميل اكتتببي وإحباط الحاجة للحب مـع الميل للانطوائية.

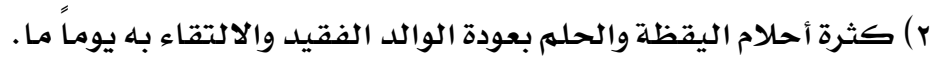

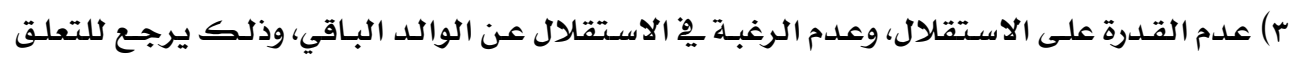

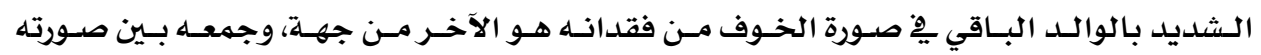

$$
\text { الحقيقية كوالد صورة الفقيد من جهة أخرىى. }
$$

ع) الخضوع والطاعة للوالد الباقي مرضاة للوالد لا غير، وذلك للتعلق الشديد بـه.

ه) الحساسية الشديدة.

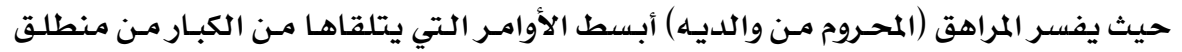

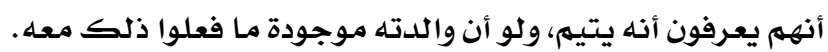

1) قلق وتشاؤم وطموح للمستقبل: وهو قلق ناشئ من عدم القدرة على مواجهـة المشاكل المحيطة بـه،

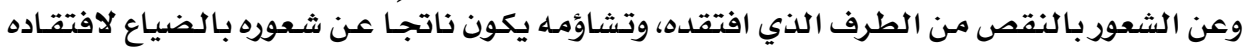

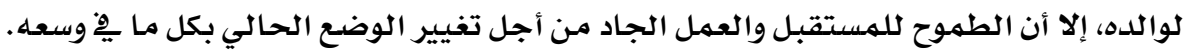

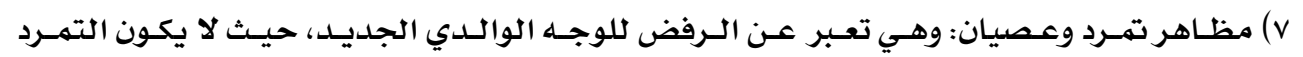

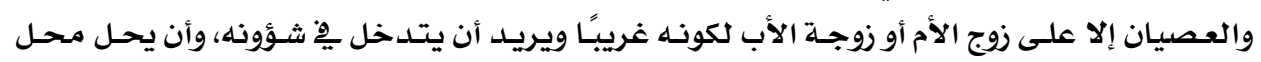

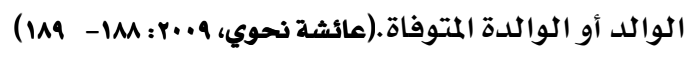

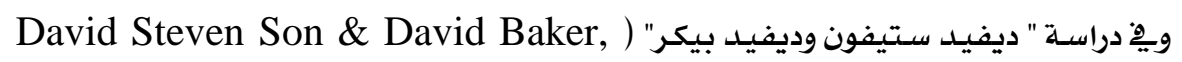

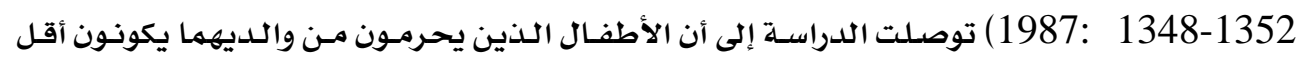

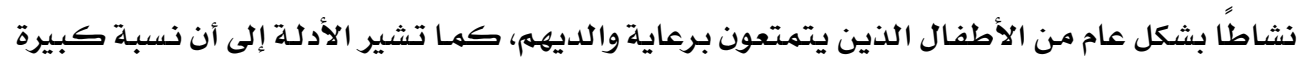

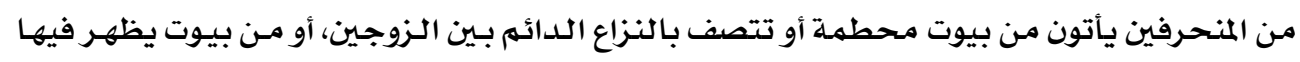

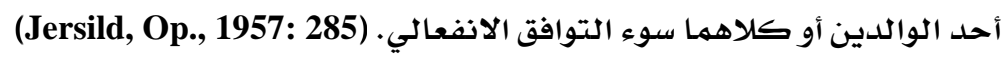

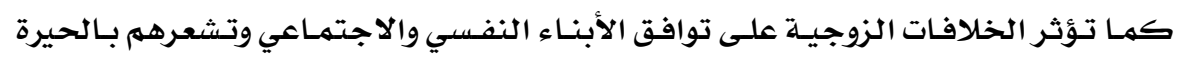

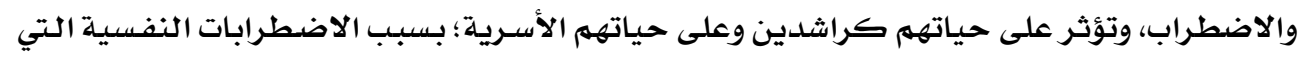

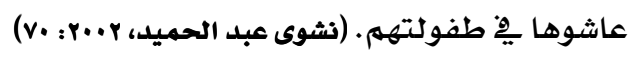

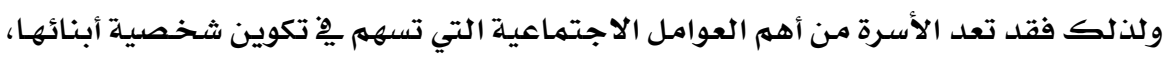

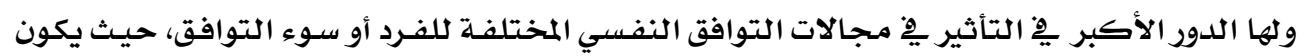

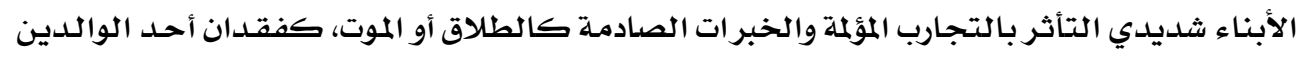

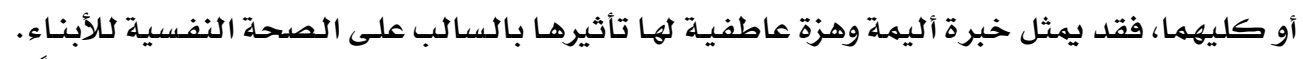

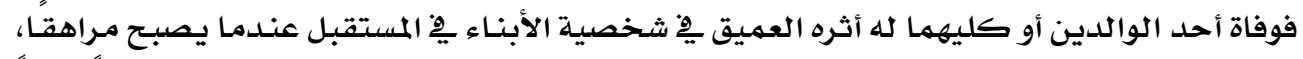

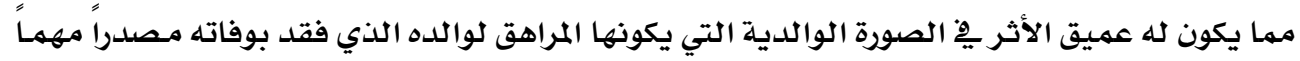

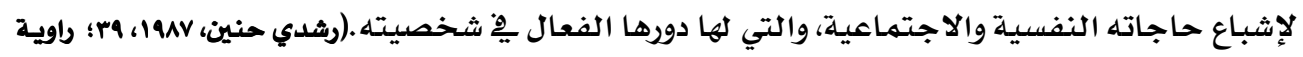

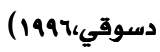


ويِّ ضوء ما سبق يمكن صياغة مشكلة الدراسة فيما يلي:

ا ـ التعرف على الفروق بين المراهقات فاقدات الأم بالوفاة، وفاقدات الأم بالطلاق، وغير فاقدات الأم مِّة

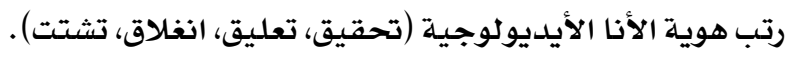

Y. التعرف على الفروق بين المراهقات فاقدات الأم بالوفاة، وفاقدات الأم بالطلاق، وغير فاقدات الأم ِِّ.

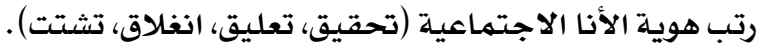

ץ. التعرف على الفروق بين المراهقات فاقدات الأم بالوفاة، وفاقدات الأم بالطلاق، وغير فاقدات الأم ِيْ

متغير التوافق الشخصى لديهن.

ثانياً: أهميية الدراسية التوافق الشخصن

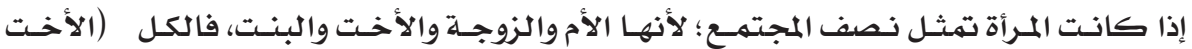

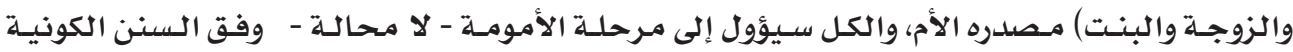

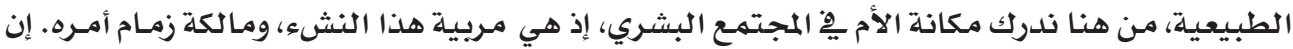

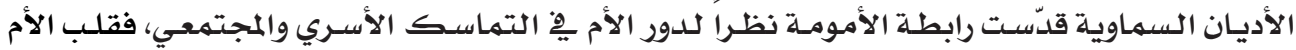

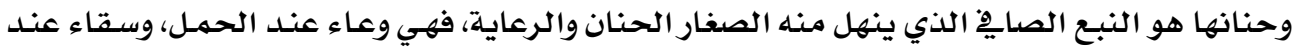

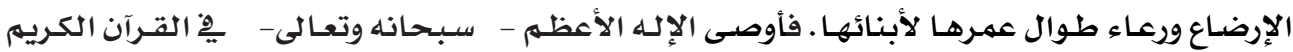

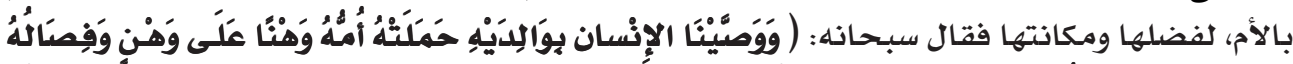

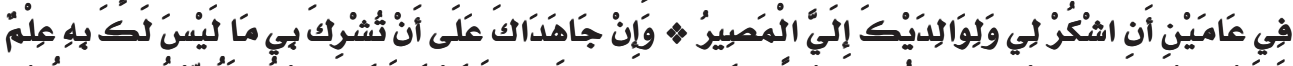

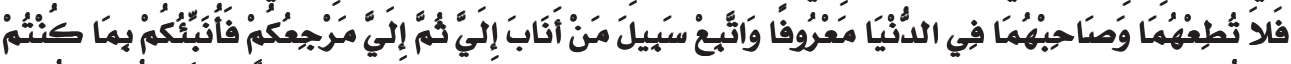

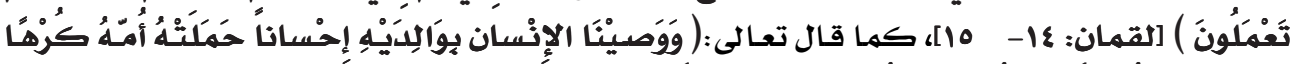

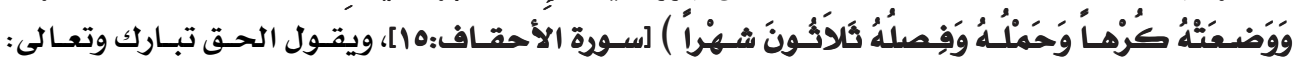

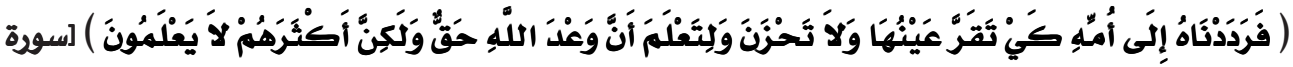

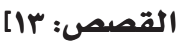

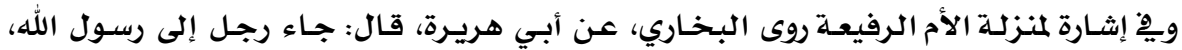

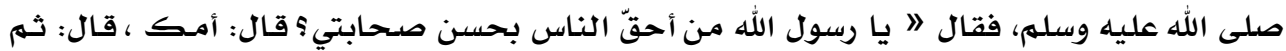

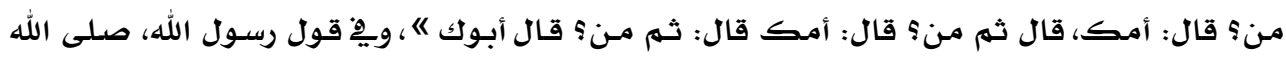

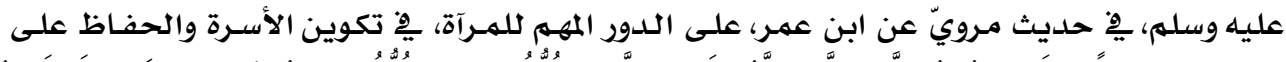

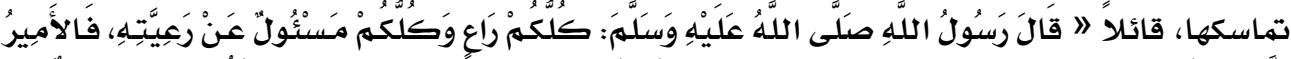

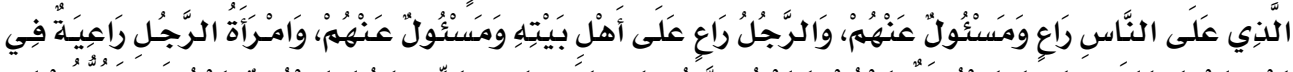

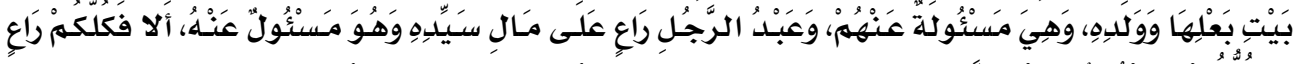

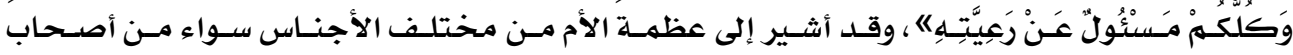

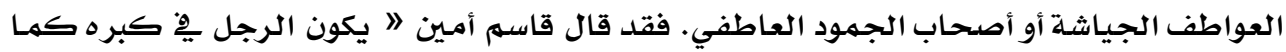

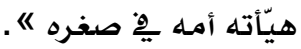


وقال نابليون بونابرت 》 إنّني مدين لأمي بكل ما حزته من الفخار، وما فزت بـه من العظمة،

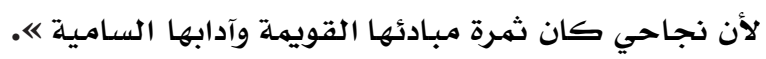

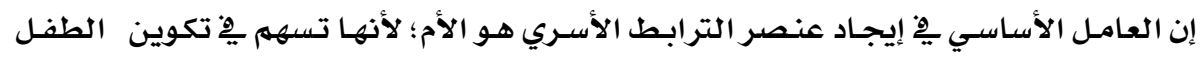

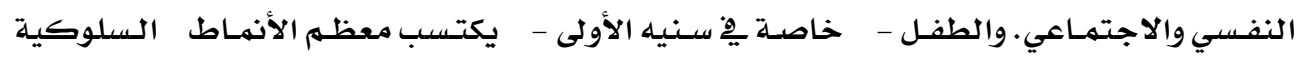

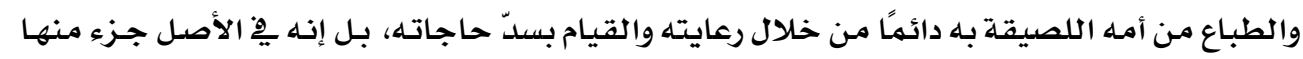

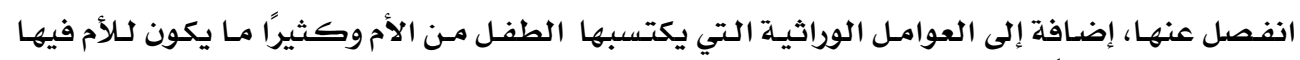

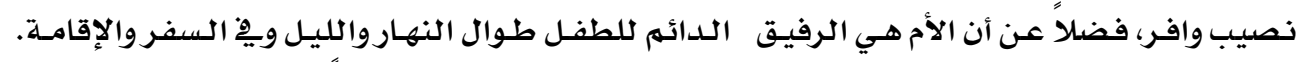

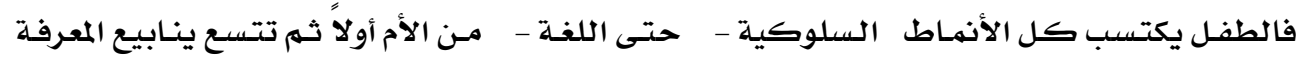

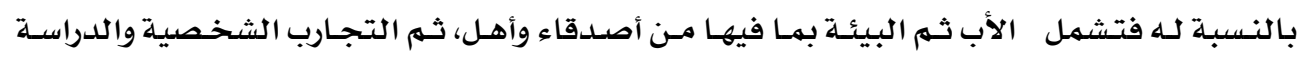

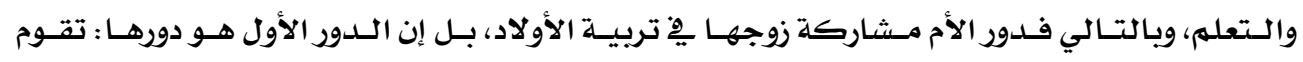
عليهن وتصلحهن.

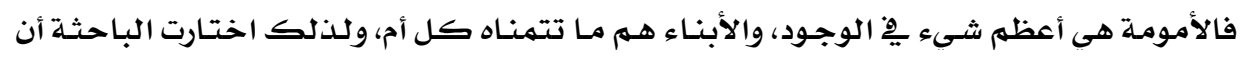

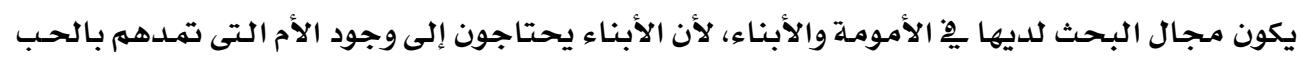

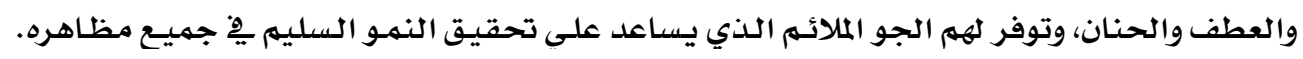

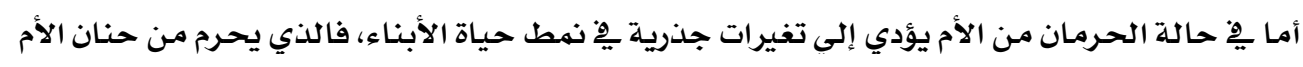

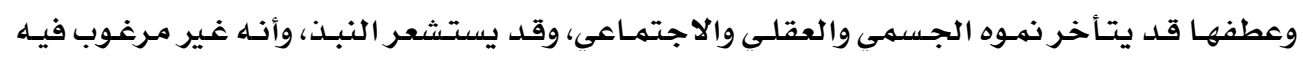

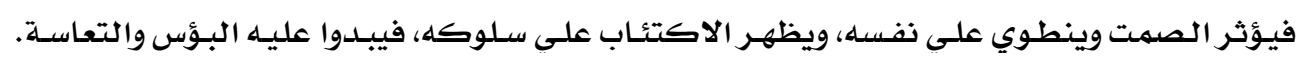

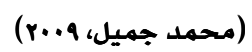

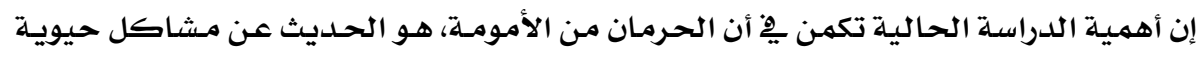

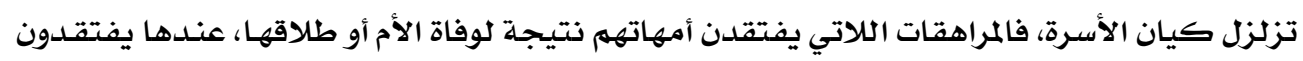

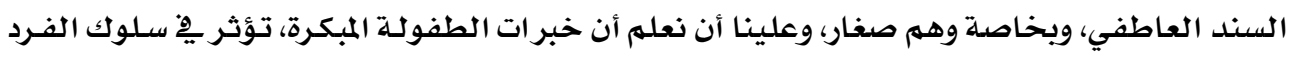

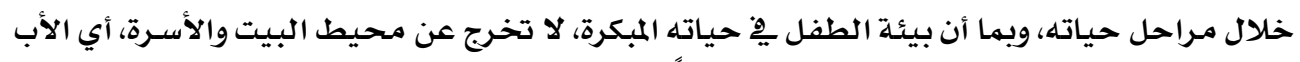

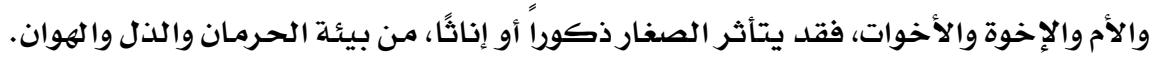
فقد حاولت الدراسـة الحالية كشف طبيعة العلاقة بين تشكل هويـة الأنا والتوافق النفسي

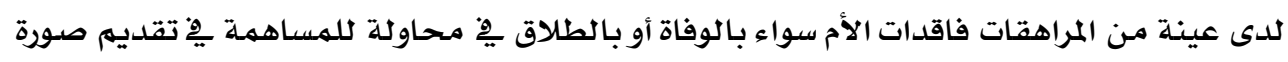

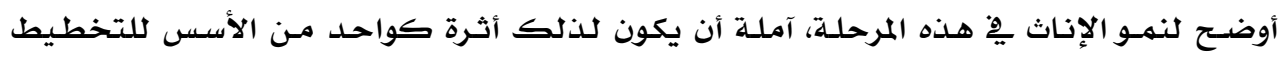
التربوي والإرشادي.

\section{وعليه يمكن تحديد أهمية الدراسة فيما يلي:}

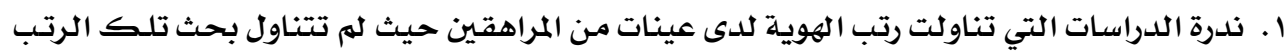

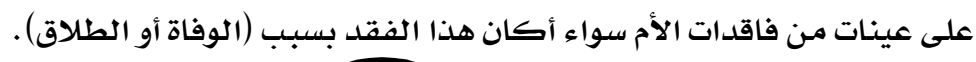




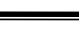

r. لم تتناول الدراسات التي تطرقت لهذا الموضوع مدى تأثير فقد الأم على التوافق الشخصى للبنـات

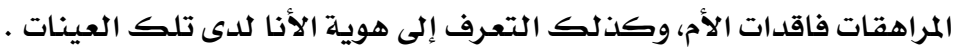
r. إثراء المجال السيكولوجي بدراسة يٌْ مجال عله النفس الاجتماعي، والتعرف من خلالها إلى مـدى

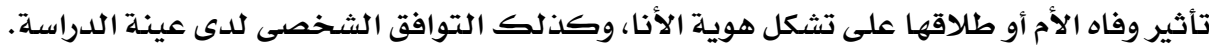
ع. تمثل نتائج الدراسلة واحدًا من الأساسات الإرشادية، قد تمد الآباء والمربين بالبيانات التي تساعدهم

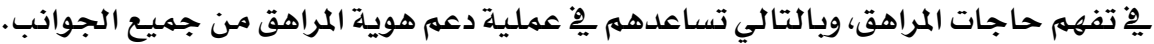

\section{ثالثا: أهداف الدراسة}

تتحدد أهداف الدراسة فِّ:

ا. الكثف عن تأثير غياب الأم بالوفاة على عينـة مـن المراهقـات يِّ مـتغير الشخصية المتوافقة، وأبعـاد

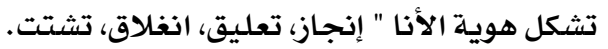
r. الكشف عن تأثير غياب الأم بالطلاق على عينة من المراهقات ِِّ مـتغير الشخصية المتوافقـة، وأبعـاد

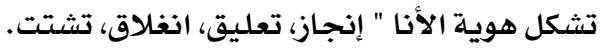

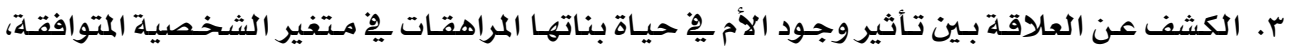

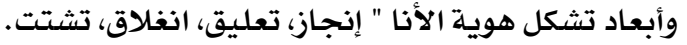

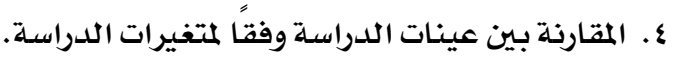
رابعاً: هصطاتحات الدراسية: أولاً: رتب الهوية:

يري "مارشيا" Marcia أن رتب الهويـة تعبر عن أريعـة أسـاليب يتبعهـا المراهقون لمواجهـة أزمسة

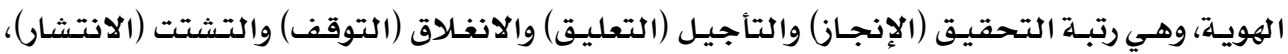

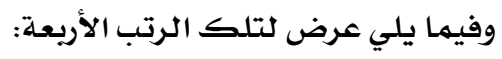

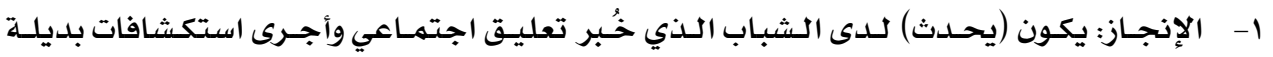

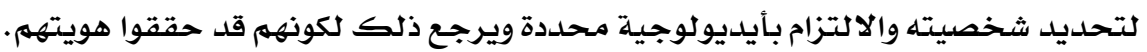

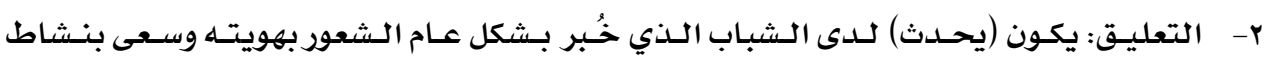

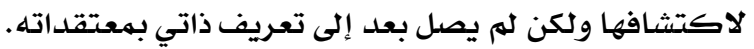

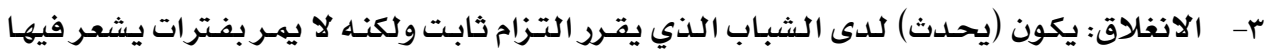

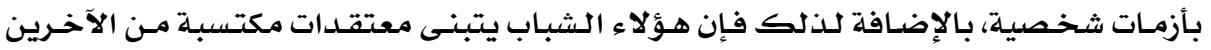

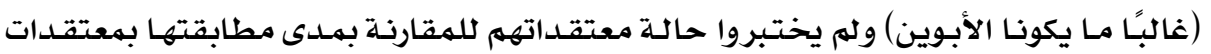

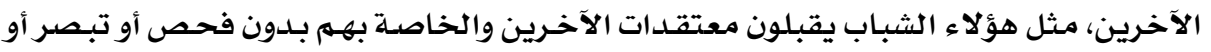

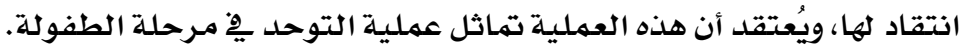




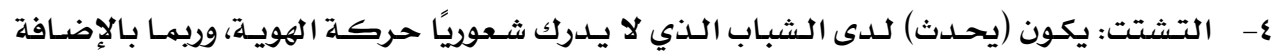

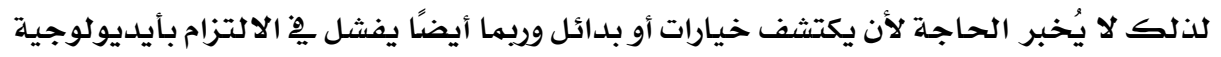

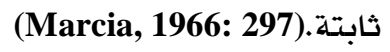

ثانيًا: التوافق الشخصى:

يقـصد بـه توافق الفـرد بـايـة مـع ذاتـه، ثـم مـع الآخـرين بشكل تكـاملـي علـي المستوى الفـردي

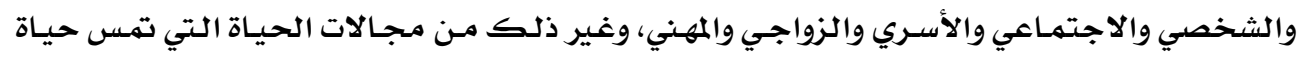

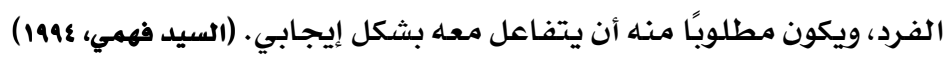

\section{خاهسا: الدراسات السابقةنة:}

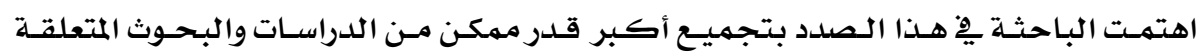

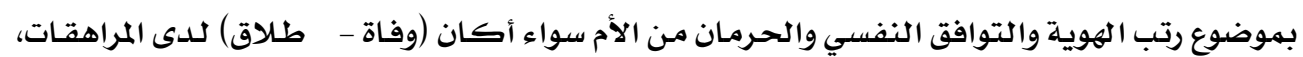

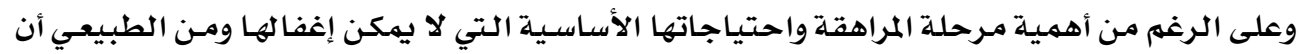

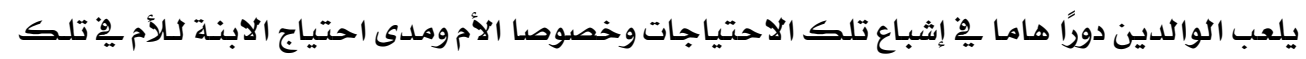

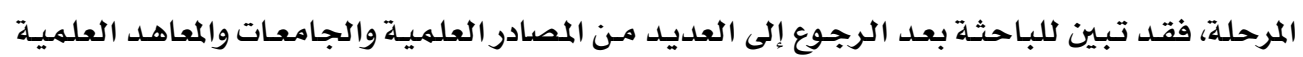

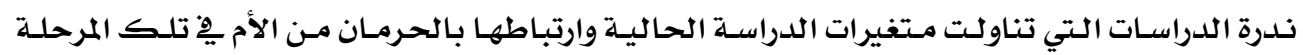

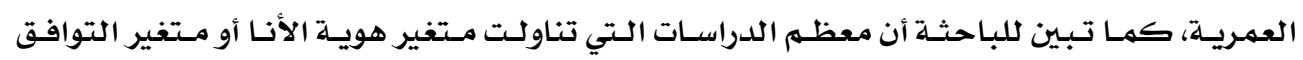

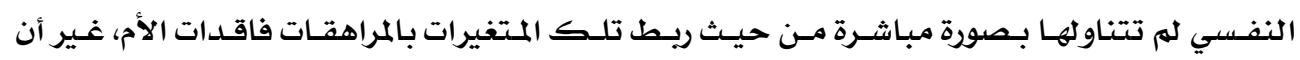

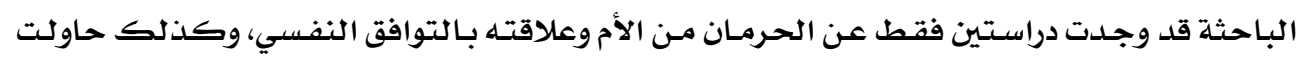

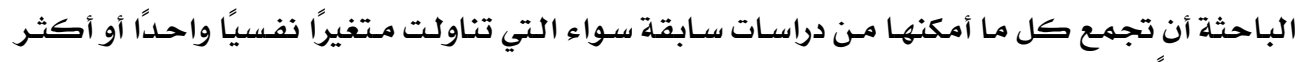

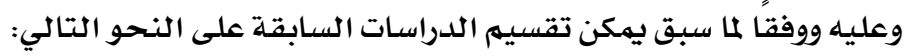

أولاً: دراسات متصلة بهوضوع الحرمان من الأم عند المراهقين. "بشكل عام"

$$
\text { 1- دراسة (إيمان فوزي سعيد، 1910): }
$$

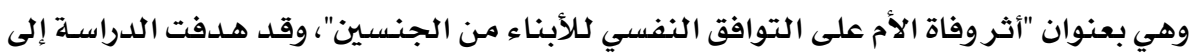

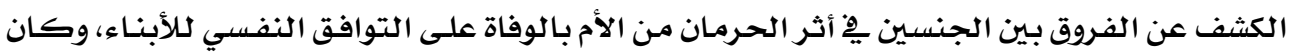

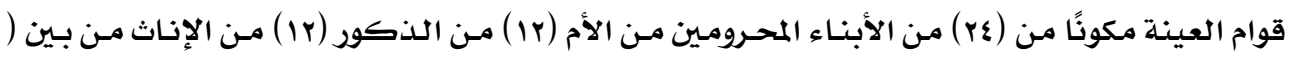

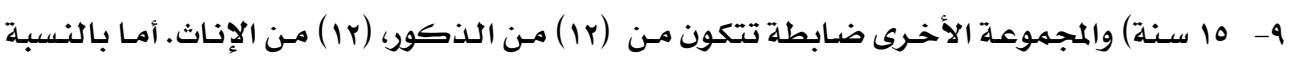

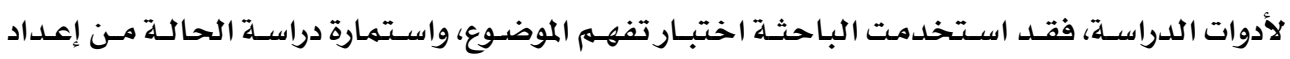
الباحثة، المقابلة الطليقة.

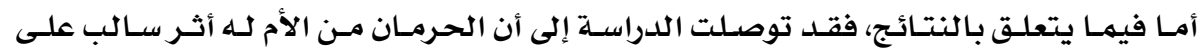

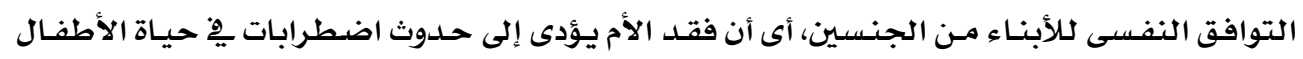


النفسية تـنعكس على تـوافقهم النفسى. وأن وفـاة الأم تخلف آثـارا أعمـق على توافق الإنـاث بـأكثر

من الذكور.

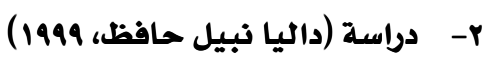

وهي بعنوان "أثر طلاق الوالدين على النضسج النفسي لأبنائهم المراهقين"، وهدفت هذه الدراسئ

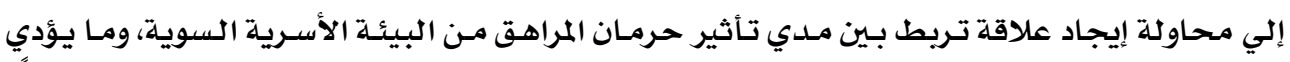

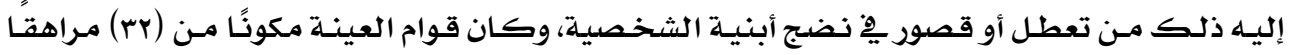

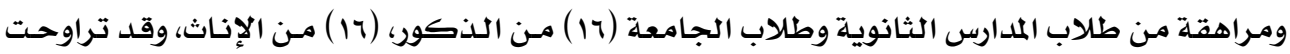

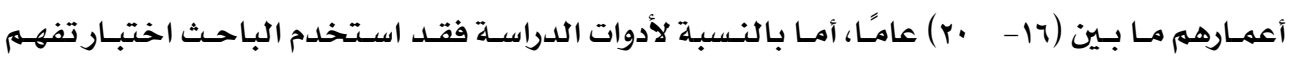

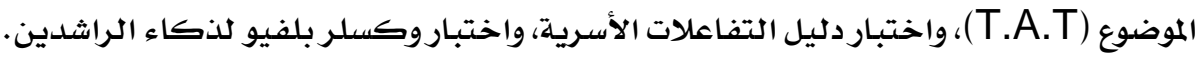

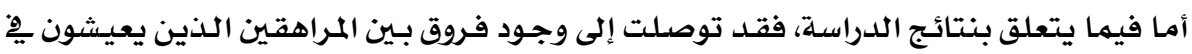

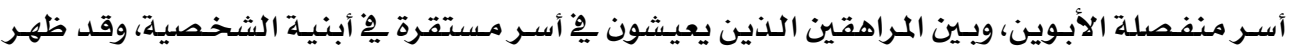

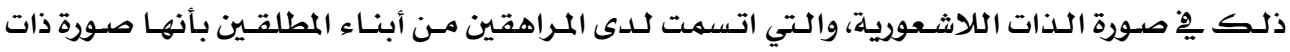

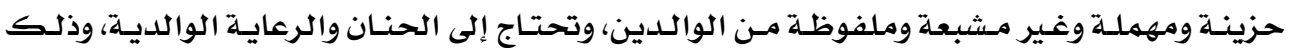

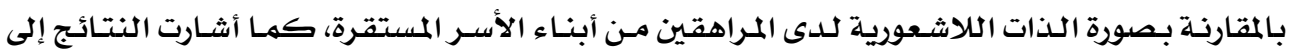

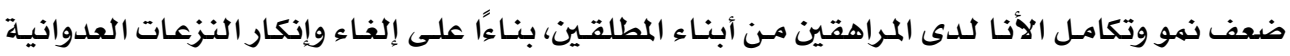

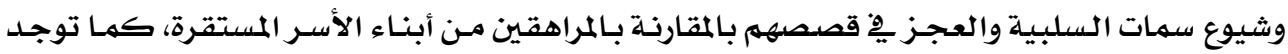

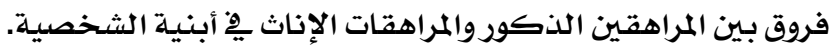
r- مراسة (رشدي عبده حنين، 194V)

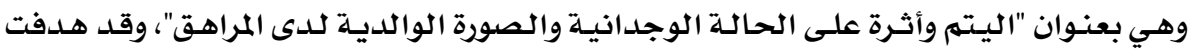

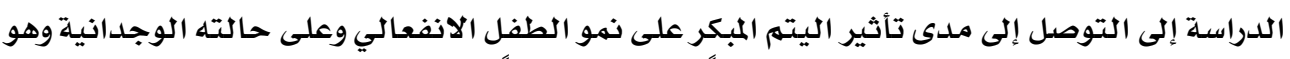

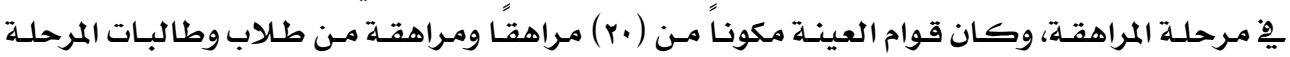

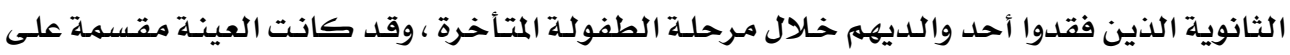

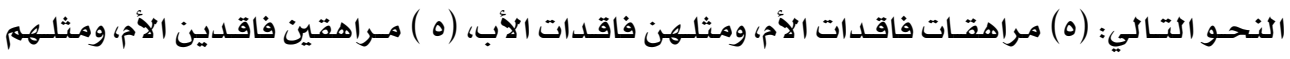

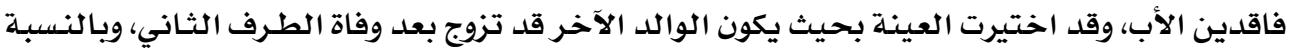

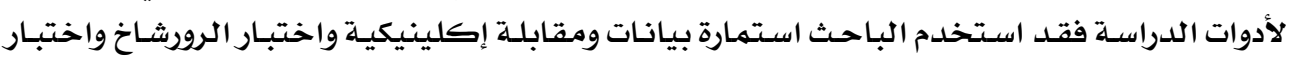
تفهم الموضوع.

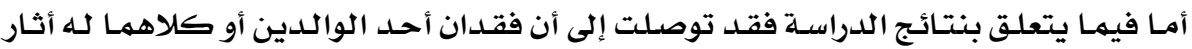

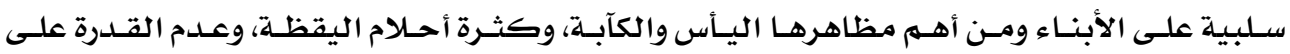
الاستقلال والخضوع والطاعة للوالد الباقي، والحساسية الشديدة وقلق ومظاهر تمرد وعصيان. 


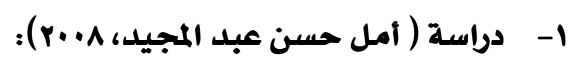

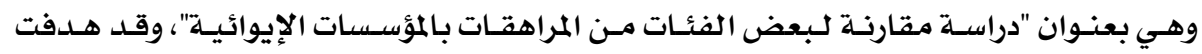

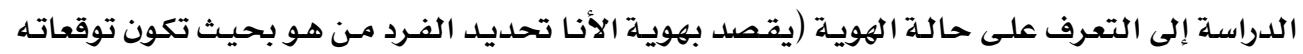

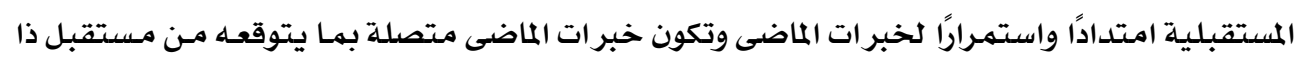

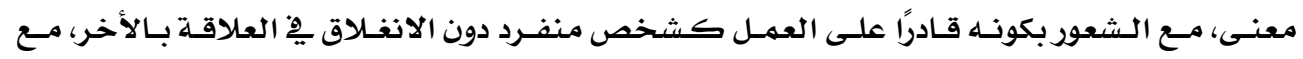

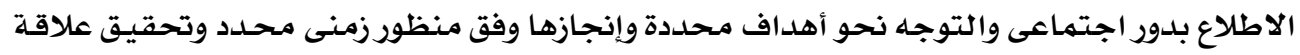

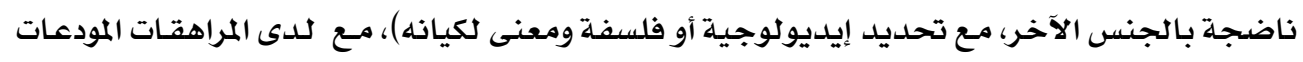

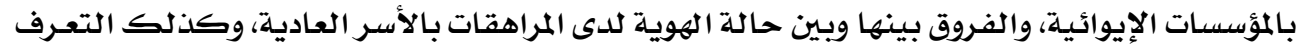
فئسة

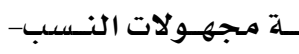

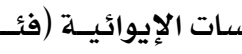

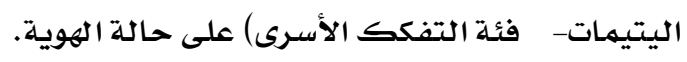

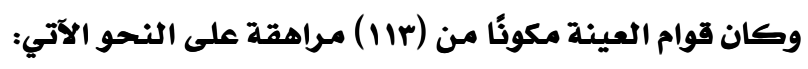

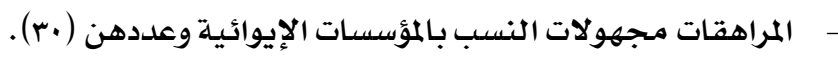

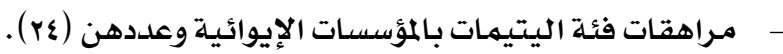

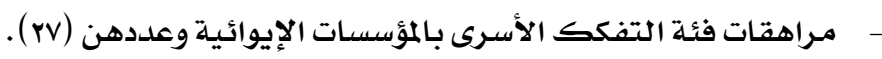
- مراهقات من الأسر العادية وعددهن (rr).

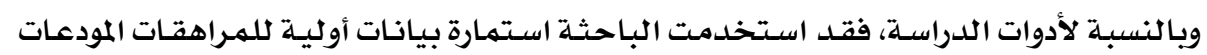

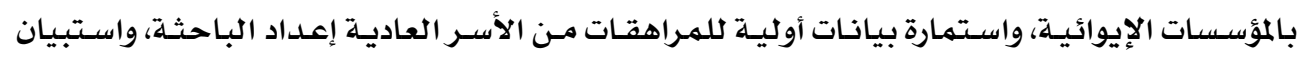

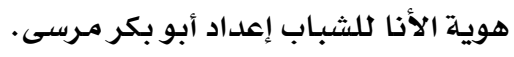

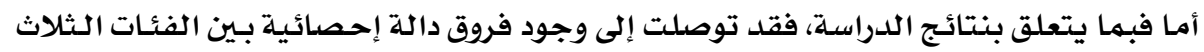

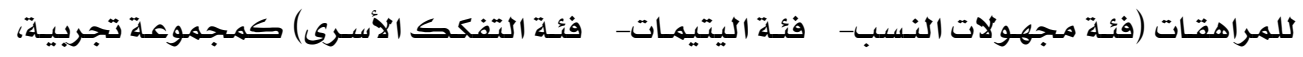

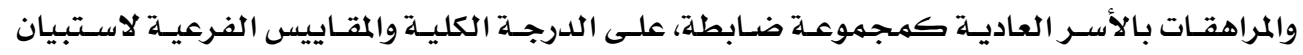
هوية الأنا.

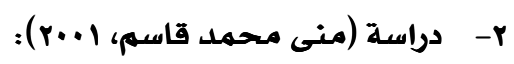

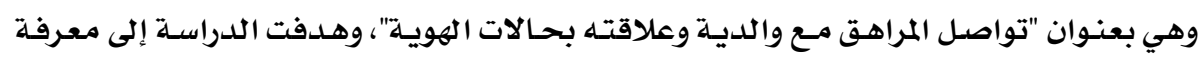

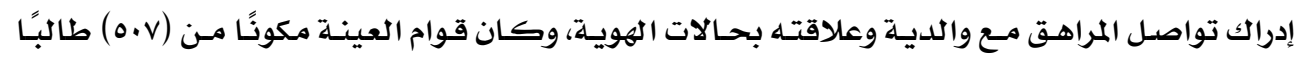

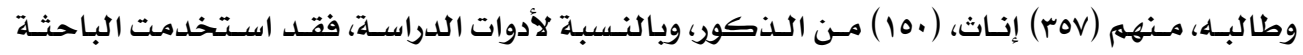

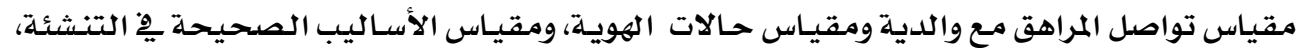

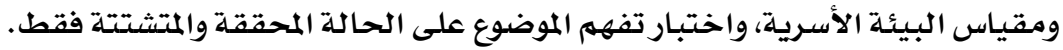




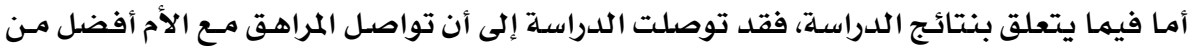

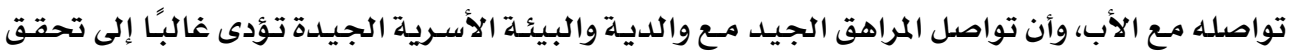

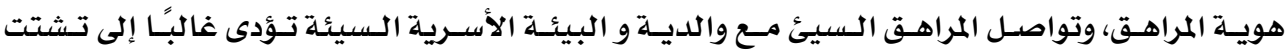
هوية المراهق.

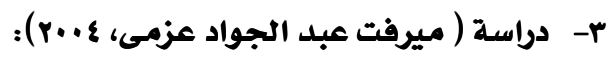

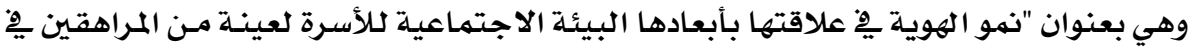

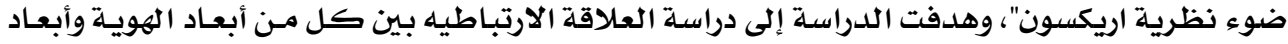

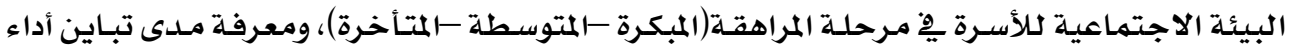

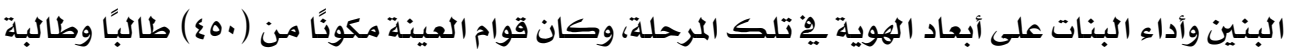

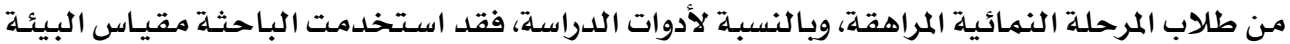
الاجتماعية للأسرة، ومقياس هوية الأنا للمراهقين.

أمـا فيما يتعلق بنتـائج الدراسـة، فقـد توصلت الدراسـة إلى وجـود علاقـة ارتباطيـه موجبـة بــين

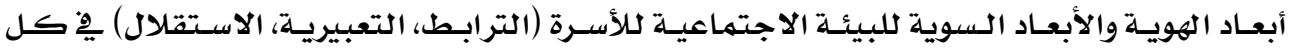

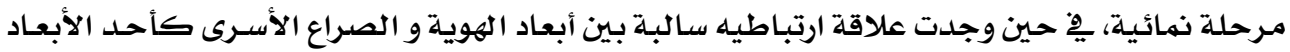

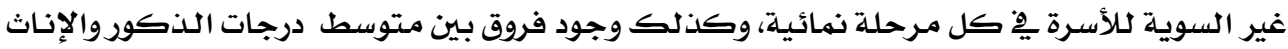

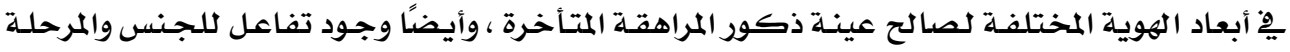

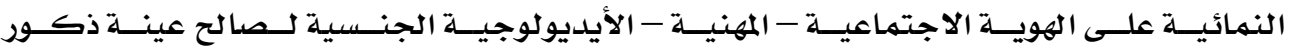
المراهقة المتأخرة. ثالثًا: دراسات متصلة بالتوافق النفسي عند المراهقين: 1- دراسة (نور الهدى عمر المقدم، • 199) :

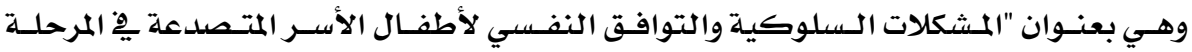

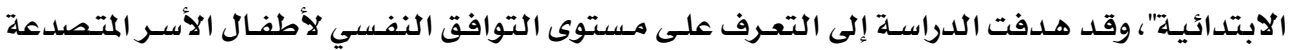

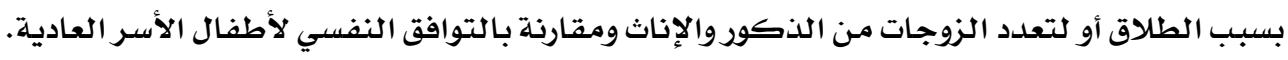

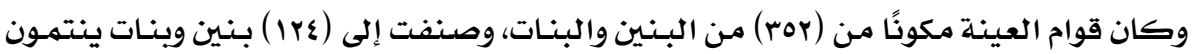

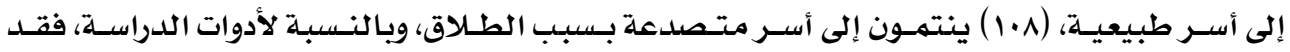

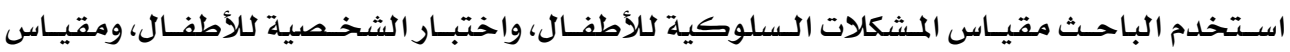
المستوى الاجتماعي والاقتصادي للأسرة.

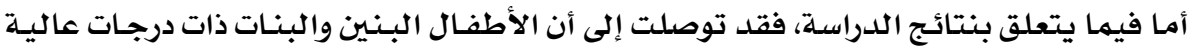

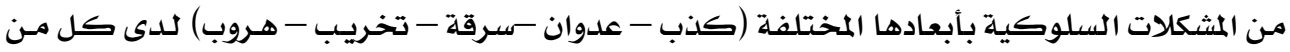

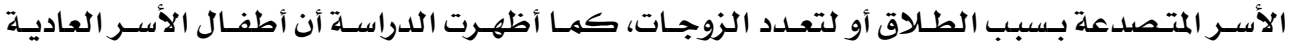




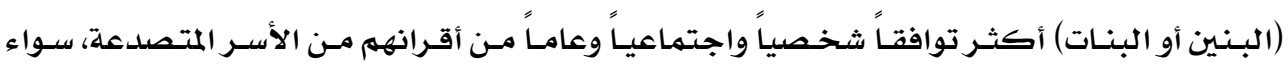
بسبب الطلاق أم لتعدد الزوجات.

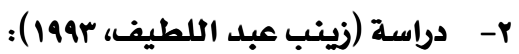

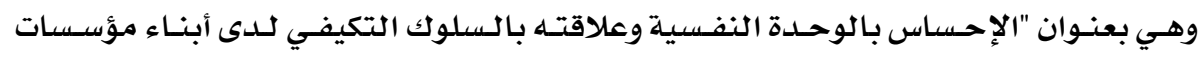

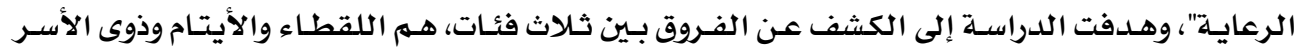

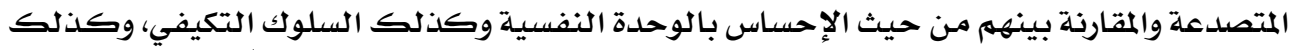

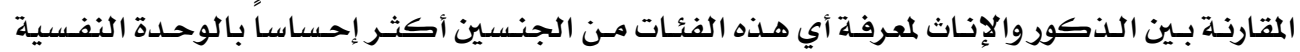

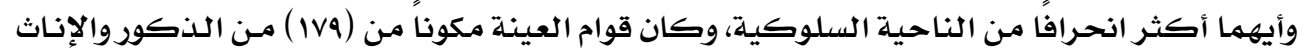

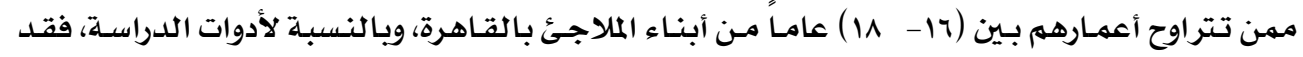
استخدم الباحث مقياس الإحساس بالوحدة النفسية، ومقياس السلوك أبناء التكيفي.

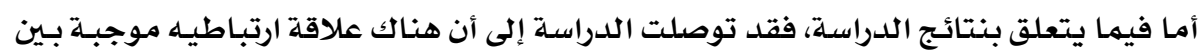

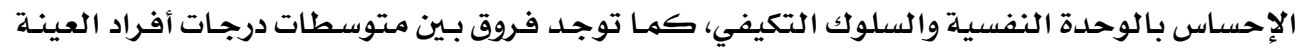

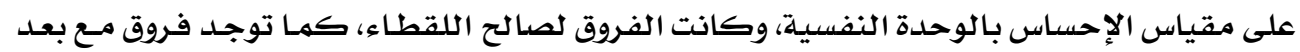

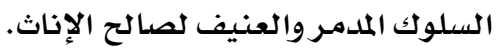

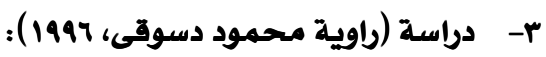

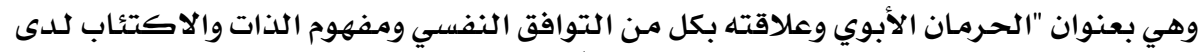

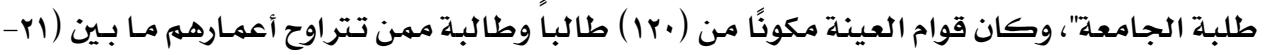

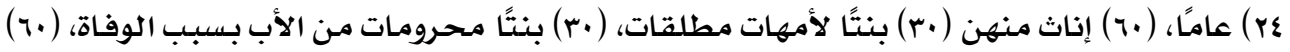

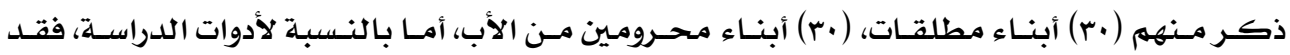

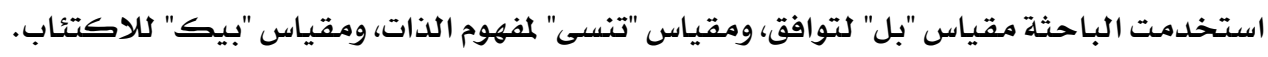

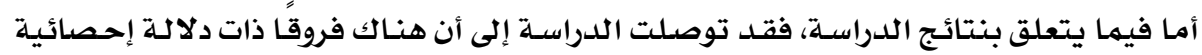

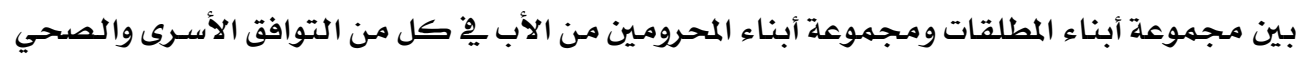

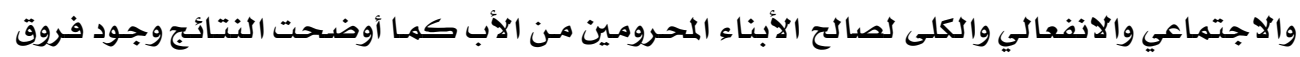

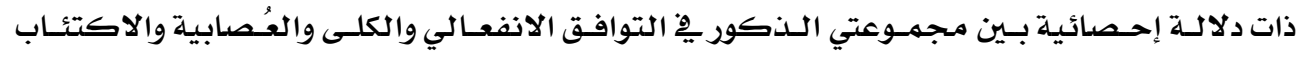

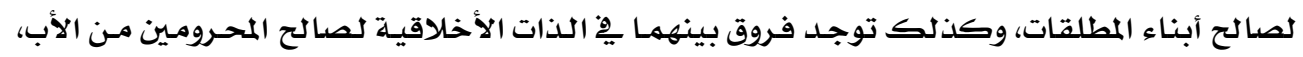

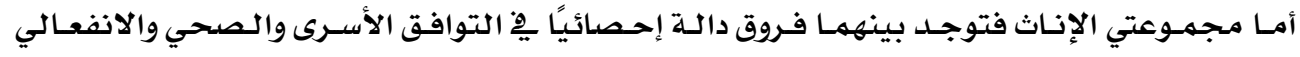

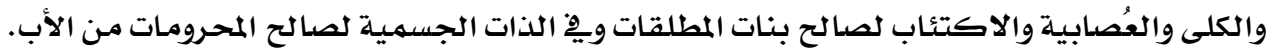




\section{سادساً: فـرض الدراسةة:}

\section{للدراسة فرض وحيد يتمثل فيما يلي:}

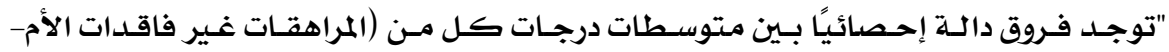

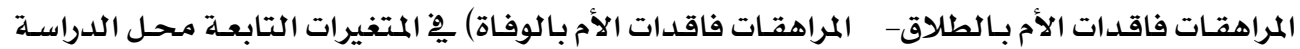

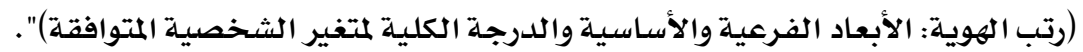

\section{سابعًا: المذهج الإجرائي للدراسة: الإدية:}

\section{أ) عينة الدراسة:}

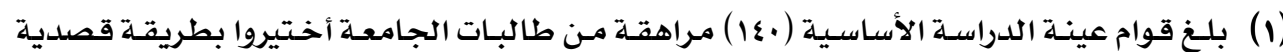

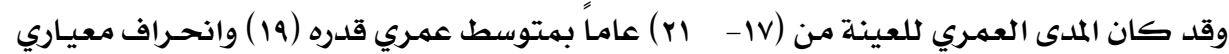

تم الحصول على أفراد عينة البحث من طالبـات جامعة المنصورة.

كان قوام هذه العينة ( ع ا ) مراهقة من طالبات الجامعة موزعين كالتالي:

$$
\begin{aligned}
& \text { 1- (.7) مـراهقة غير فاقدات الأم. } \\
& \text { r - (ع ) مراهقة فاقدات لتلأم بالطلاق. }
\end{aligned}
$$

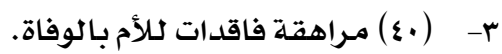

إجراءات التطبيق:

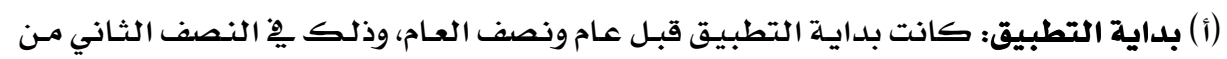

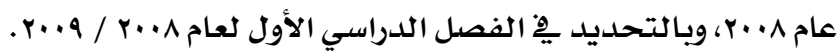

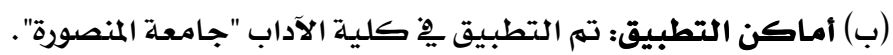

$$
\text { (ج) طبيعة التطبيق: تم التطبيق بصورة جمعية. }
$$

(د) كيفية التطبيق: تم عمل بطارية الاختبارات وهي مكونة من استمارة بيانات أولية من إعداد

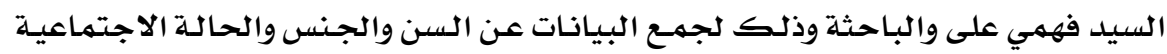

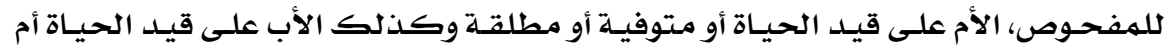

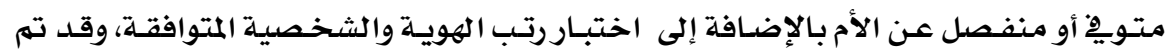

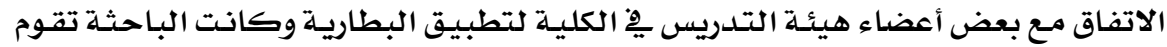

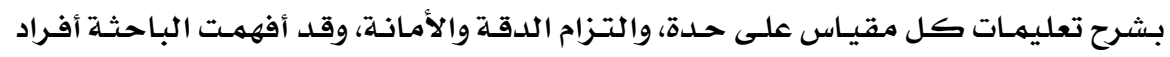




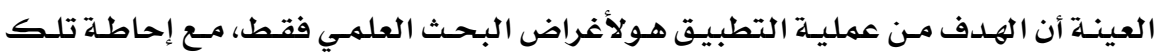
المعلومات بالسرية التامـة، وأخذ التطبيق مدة التهيق حوالي ثلاثة أشهر لإنهائه.

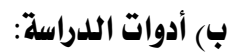
تكونت أدوات الدراسة مما يلي:

إعداد /محمد السيد عبد الرحمن.

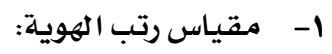

إعداد / السيد فهمي علي.

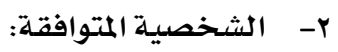

(0) (0) الأسلوب الإحصائي:

اشتملت عينة الدراسـة الأساسية على الأساليب الإحصائية التالية:

$$
\begin{aligned}
& \text { 1. حسـاب المتوسطات الحسابية. } \\
& \text { r. . حساب الانحرافات المعيارية. }
\end{aligned}
$$

r. تحليل التباين أحادى الاتجاه متعدد المتغيرات التابعة MANOVA.

ع. المقارنات المتعددة باستخدام أسلوب توكي.

ثامهنا: نتائج الدراسة:

$$
\text { نص فرض الدراسـة على ما يلي: }
$$

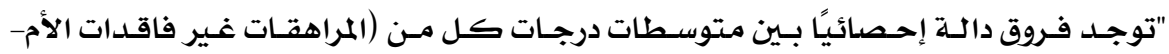

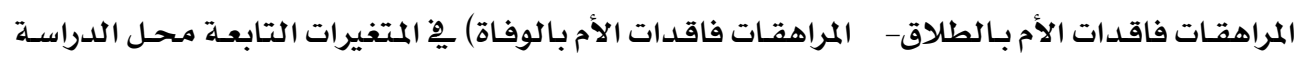

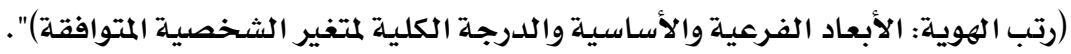

\section{مناقشة تتيجة الفرض وتفسيرها:}

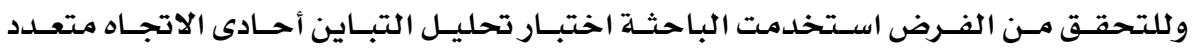

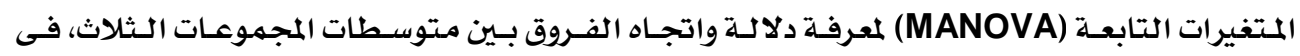

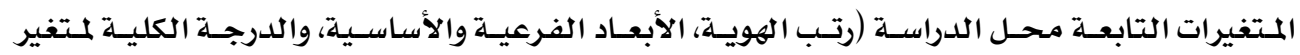

الشخصية المتوافقة. وفيما يلى عرض للنتائج ومناقشتها.

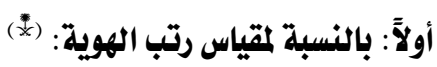

ا- الدرجة الكلية لمقياس إنجاز الهوية. "تحقيق هوية الأنا"

بالنظر ٍِِ الجدول الآتى المتعلق بقيم مدى "توكي" لحساب اتجاه الفروق بين العينـات الثلاثة

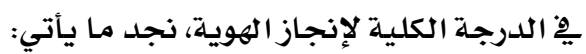

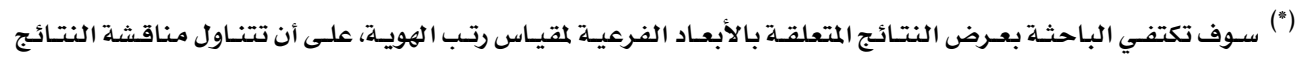

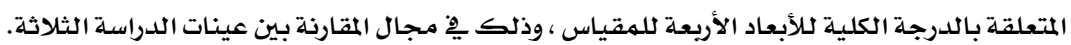


مجلة بحوث التربية النوعية - علد rr - أكتوير rا r r r

جدول ( ) قيم مدى "توكي" لاتجاه الفروق بين متوسطات درجات المجموعات الثلاث،

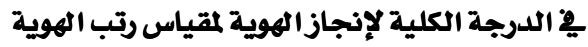

\begin{tabular}{|c|c|c|c|}
\hline \multicolumn{2}{|c|}{ المجموعات الفرعية } & \multirow{2}{*}{ j } & \multirow{2}{*}{ المجموعات } \\
\hline 2 & 1 & & \\
\hline & 42.7000 & 40 & فاقدات الأم بالوفاة \\
\hline 47.1167 & 47.1167 & 60 & غير فاقدات الأم المراهقات \\
\hline 50.3250 & & 40 & فاقدات الأم بالطلاق \\
\hline .444 & .217 & & مستوى الدلالة \\
\hline
\end{tabular}

أ- لم تكن هناك فروق دالة بين فاقدات الأم بالوفاة وغير فاقدات الأم ِِّ إنجاز الهوية.

ب - أيضا لهم تكن هناك فروق دالة بين غير فاقدات الأم وفاقدات الأم بالطلاق ِِّ إنجاز الهويـة.

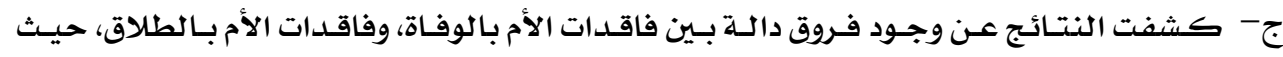

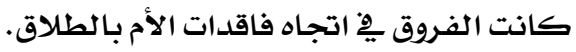

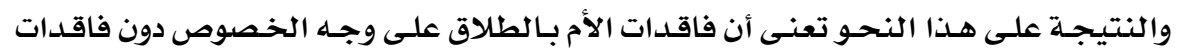

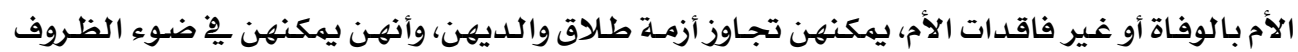

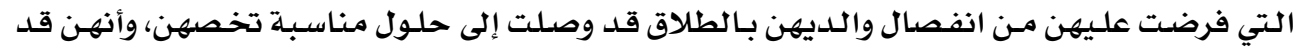

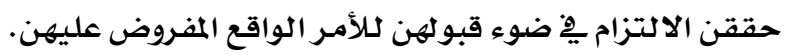

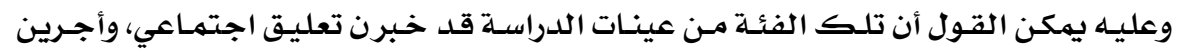

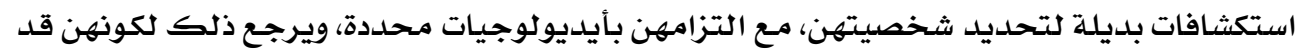

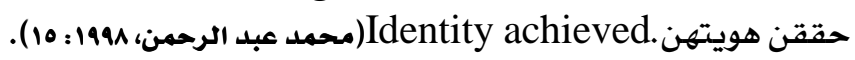

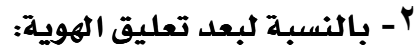

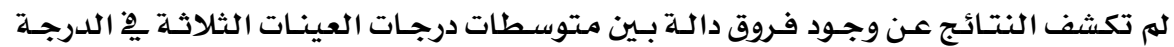

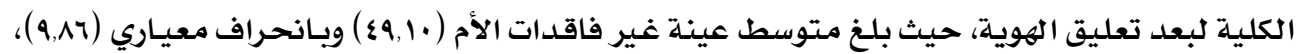

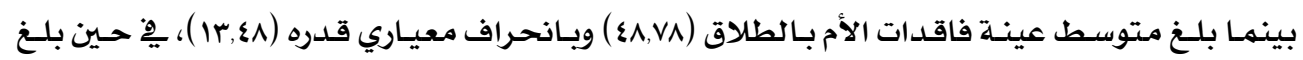

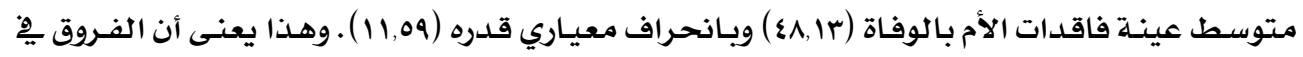

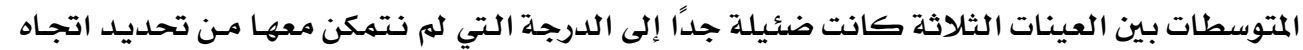

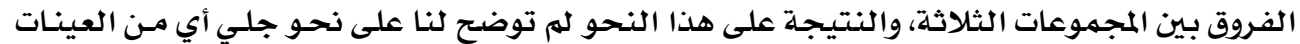

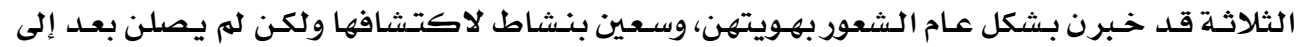

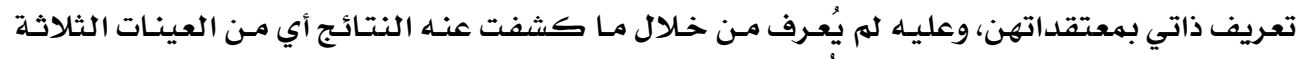

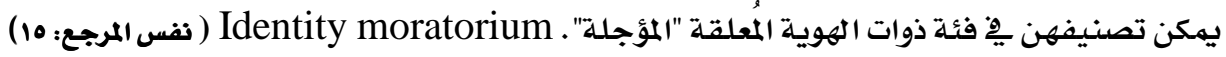




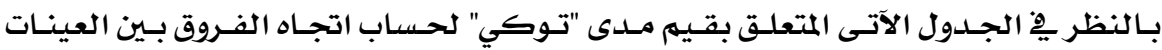

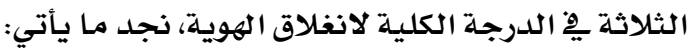
جدول (r) قيم مدى توكي لاتجاه الفروق بين متوسطات درجات المجموعات الثلاث

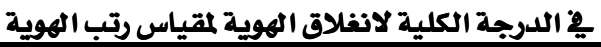

\begin{tabular}{|c|c|c|c|}
\hline \multicolumn{2}{|c|}{ المجموعات الفرعية } & \multirow{2}{*}{$\mathrm{N}$} & \multirow{2}{*}{ المجموعات } \\
\hline 2 & 1 & & \\
\hline & 62.5167 & 60 & غير فاقدات الأم المراهتات \\
\hline 65.8250 & 65.8250 & 40 & فاقدات الأم بالطلاق \\
\hline 71.4000 & & 40 & فاقدات الأم بالوفاة \\
\hline .180 & .542 & & Sig. \\
\hline
\end{tabular}

أ- عدم وجود فروق دالة بين غير فاقدات الأم، وفاقدات الأم بالطلاق فِ انغلاق الهوية. ب- عدم وجود فروق دالة بين فاقدات الأم بالوفاة وفاقدات الأم بالطلاق يِّ انغلاق الهوية. ج- كانت هناك فروق دالة بـين فاقدات الأم بالوفاة وغير فاقـدات الأم ِِّ انغلاق الهويـة حيث كانت الفروق يِّا اتجاه فاقدات الأم بالوفاة.

والنتيجة على هذا النحو تعنى أن عينة فاقدات الأم بالوفاة ريما يقررن التزام ثابت، ولكنهن

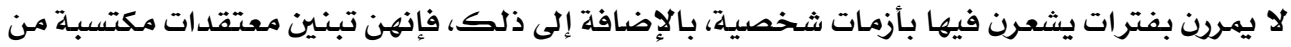

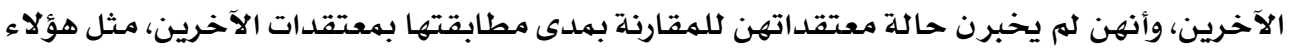

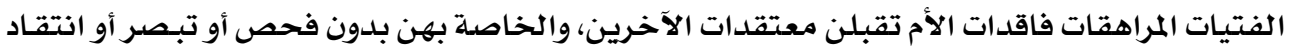

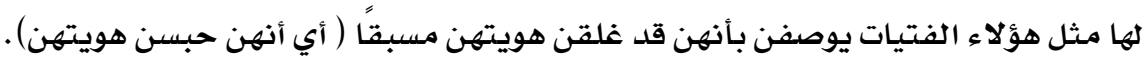

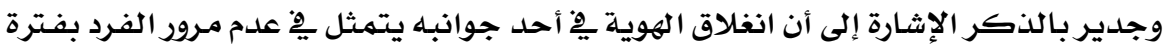

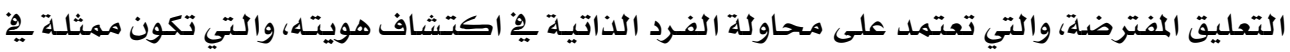

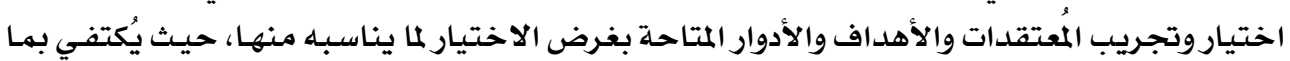

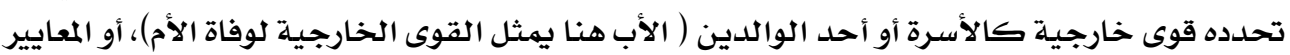

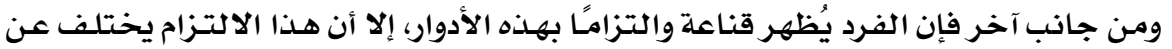

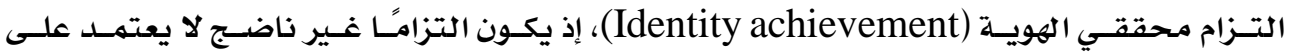
الاختيار الذاتي بما يحلدد لهم الأهداف. 


\section{ع - بالنسبة لبعد تشتت الهوية:}

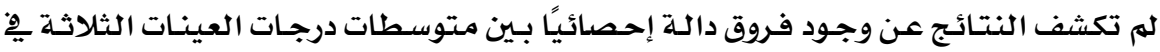

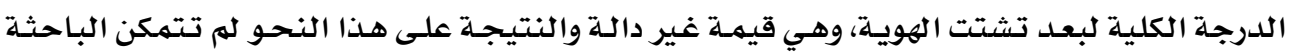

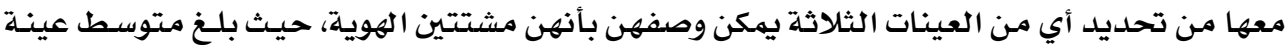

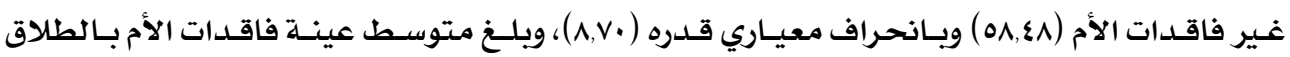

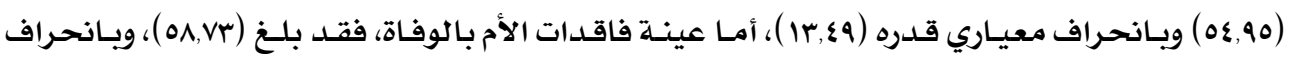
معياري قدره (11,rهو).

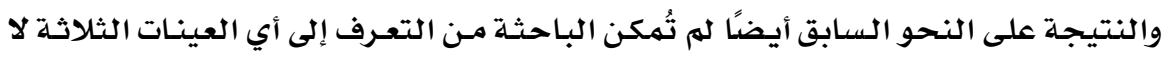

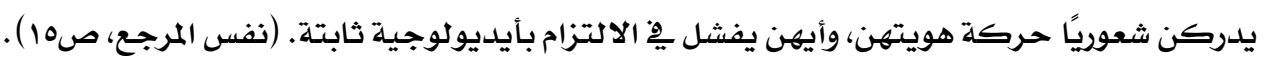

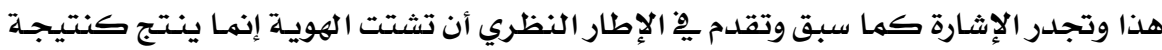

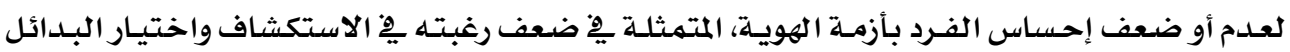

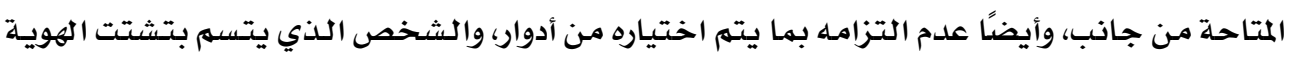

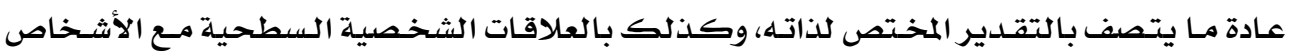

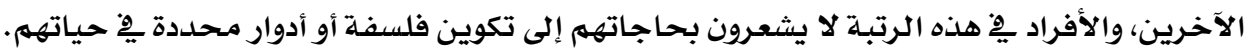

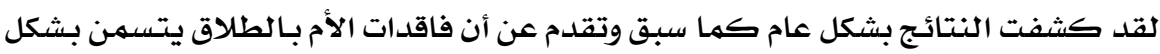

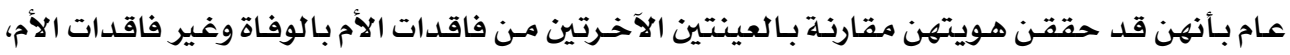

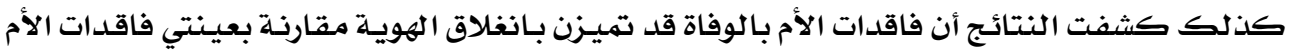

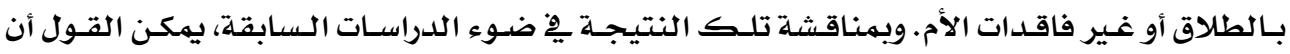

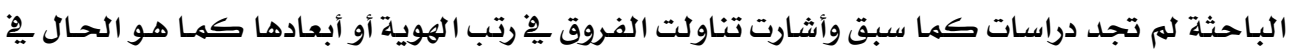

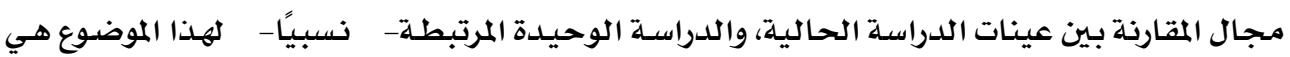

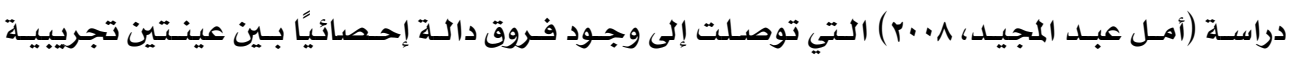

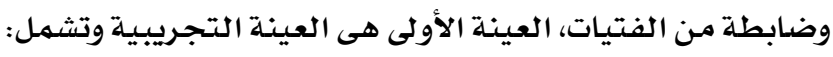

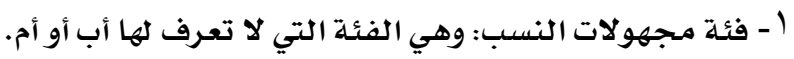

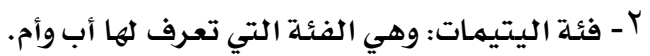
r - فئسة التفكك الأسرى سواء بالانفصال أو بالطلاق.

أما العينة الضابطة فتشهمل:

$$
\text { فئة المراهقات الكلاتي يعشن مـع والديهما. }
$$

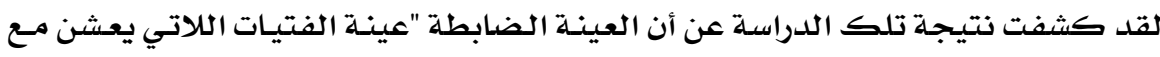

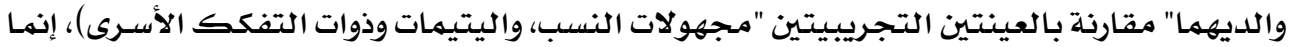

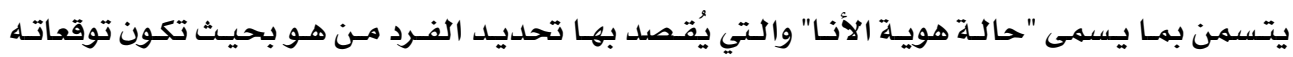

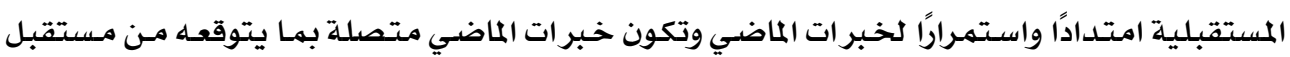


اتصالاً ذا معنى، مـع الشعور بكونه قادرًا على العمل كشخص منفــرد دون الانغلاق يِّ العلاقـة بـالأخر،

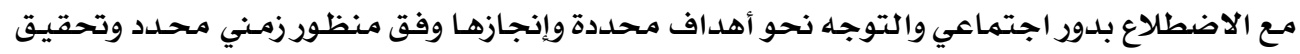

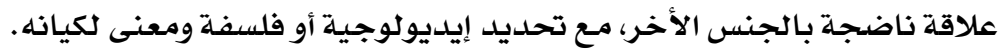

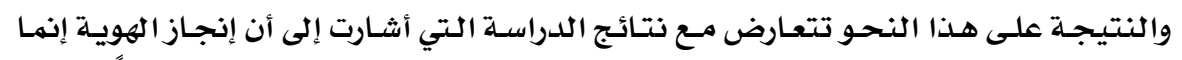

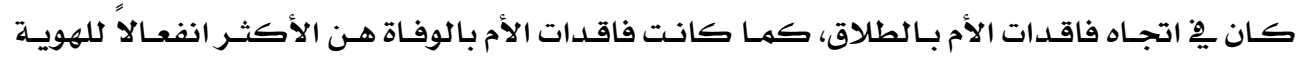

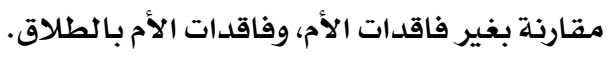

غير أن هناك ما يمكن استخلاصده مـن الدراسات السابقة، ويهكن أن يتفق مـع نتائج الدراسـة

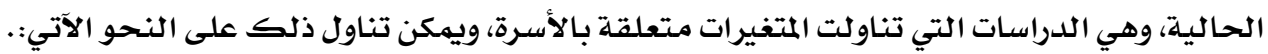

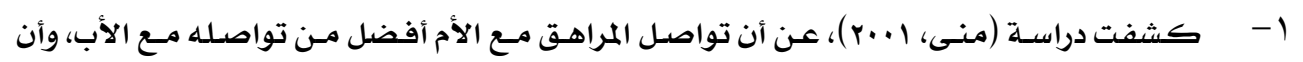

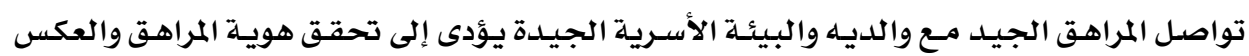

$$
\text { يؤدى إلى تشتت الهوية للمراهق. }
$$

وهـذه النتيجــة تؤكس على أهميـة وجـود الأبـوين خصوصًا الأم، وهـذا يـدعم نتيجـة الدراسـة

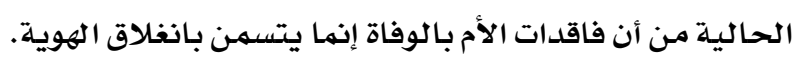

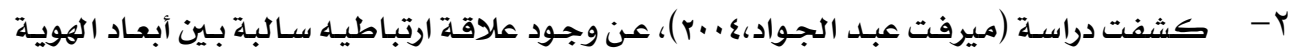

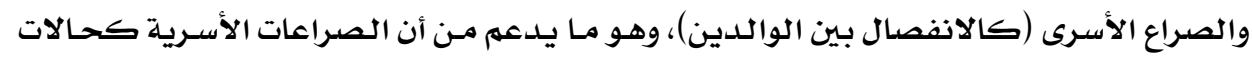

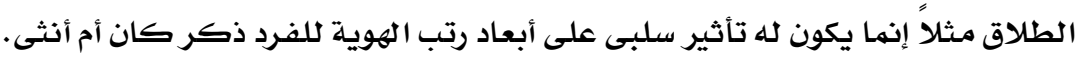

\section{ثانيًا: بالنسبة لمقياس الشخصية المتوافقة:}

بالنظر ِِّ الجدول الآتى المتعلق بقيم "توكي" لحساب اتجاه الفروق بـين العينـات الثلاثة ـِيْ

مقياس الشخصية المتوافقة، نجد ما يأتي: جدول (r) قيم مدى "توكي" لاتجاه الفروق بين متوسطات درجات المجموعات الثثلاث

\begin{tabular}{|c|c|c|c|}
\hline \multicolumn{2}{|c|}{ المجموعات الفرعية } & \multirow{2}{*}{ j } & \multirow{2}{*}{ المجموعات } \\
\hline 2 & 1 & & \\
\hline & 136.9000 & 40 & فاقدات الأم بالطلاق \\
\hline 145.9500 & 145.9500 & 60 & غير فاقدات الأم المراهقات \\
\hline 149.9750 & & 40 & فاقدات الأم بالوفاة \\
\hline .635 & .105 & & مستوى الدلالة \\
\hline
\end{tabular}

2 2 الدرجة الكلية للشخصية المتوافقة

أ- لا توجد فروق دالة بين عينة فاقدات الأم بالطلاق وغير فاقدات الأم ِِِ الشخصية المتوافقة. ب - كذلك لا توجد فروق بين غير فاقدات الأم، وفاقدات الأم بالوفاة بِ الشخصية المتوافقة. 


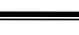

ج- توجد فروق دالة بين عينتي فاقدات الأم بـالطلاق، وفاقدات الأم بالوفاة يِّ الشخصية المتوافقة، وذلك يِّ اتجاه فاقدات الأم بالوفاة.

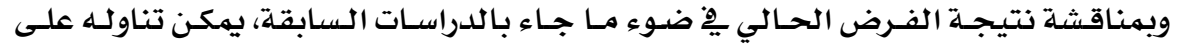

النحو الأتي:

أ- دراسة (نور الهدى، 199 19)، كشفت عن أن أطفال الأسر المتصدعة بسبب الطلاق أو تعـدد الزوجـات

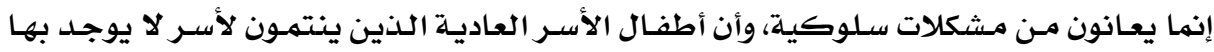

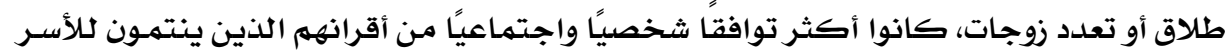

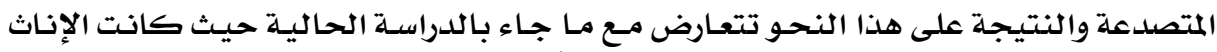

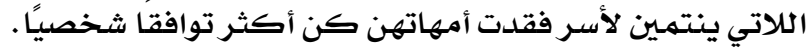

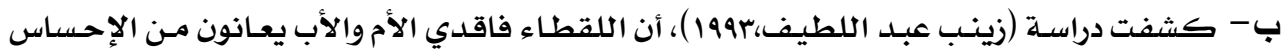

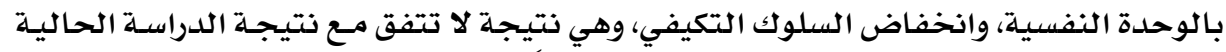

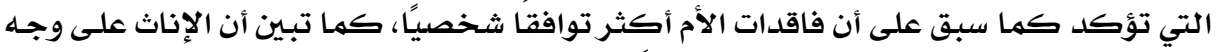
الخصوص كن أكثر سلوكا تدميريًا وعنيفًا.

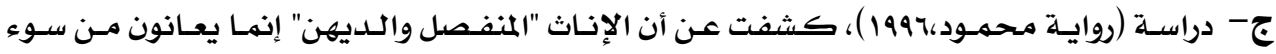

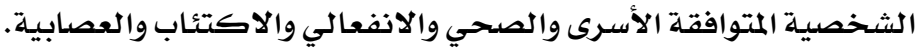

وتعلق الباحثة على النتيجة السابقة بأنها كانت تتوقع أن يكون اتجاه الفروق يِّ الشخصية

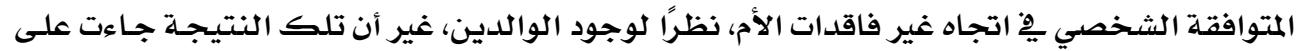

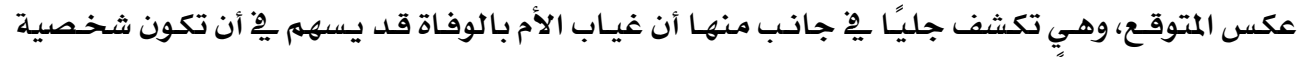

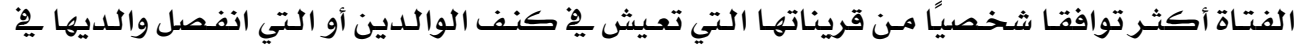

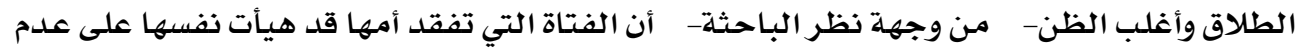

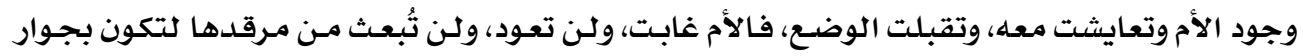

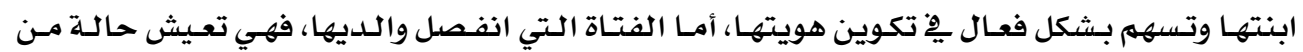

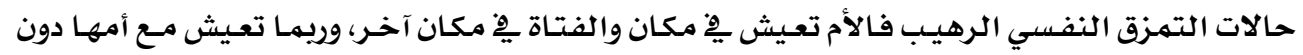

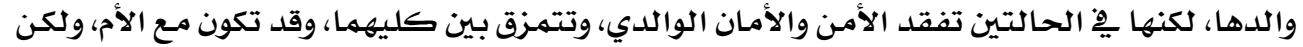

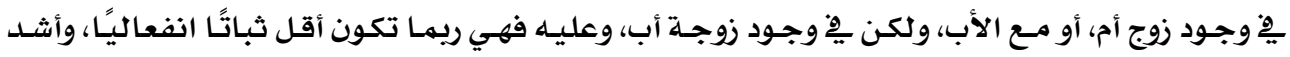

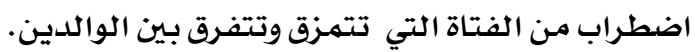
هذا فضلا عن أنها ريما لا تعيش مـع أي منها فقد تكون ِِّ كنف جديها أو أحدهما أو مـع أي

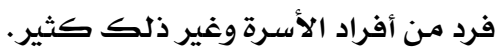

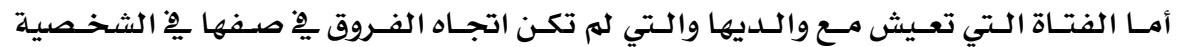

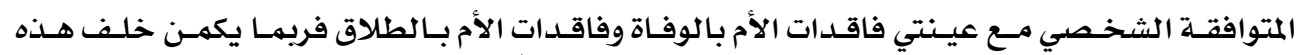

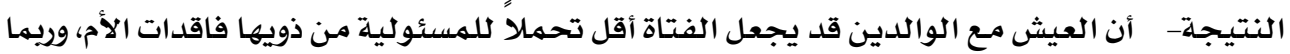

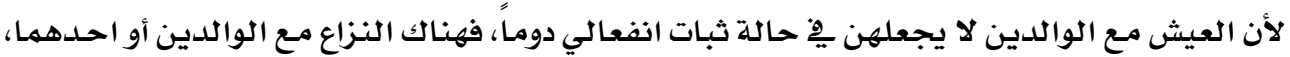


وهناك صراع الأجيال وهناك الاطمئنان إلى أن أي حالة من حالة التذمر أو التمردد من قبل الأبناء لن

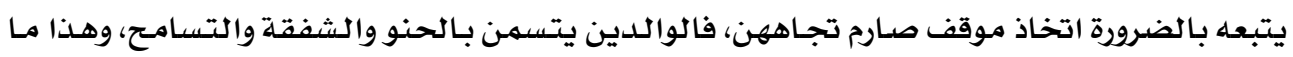

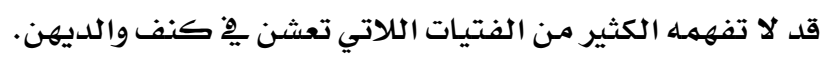

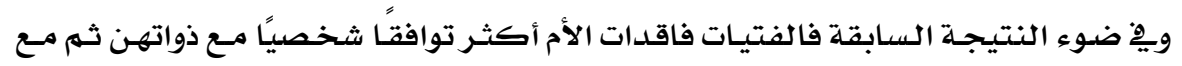

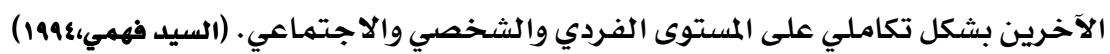

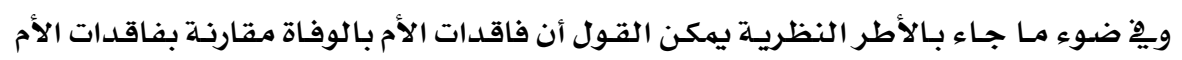

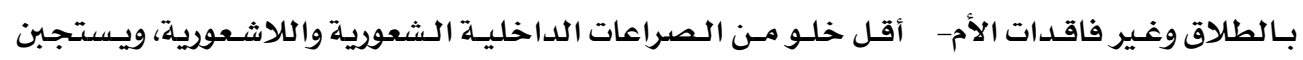

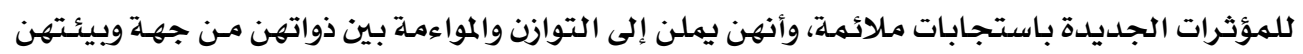
من جهة أخرى.

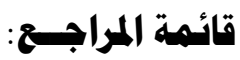

\section{أولاً: المراجع باللفة العربية:}

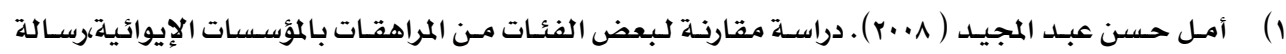

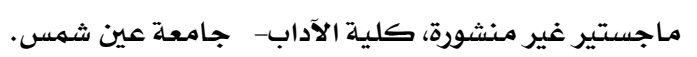

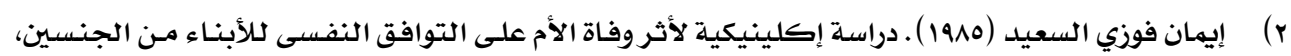

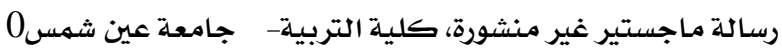

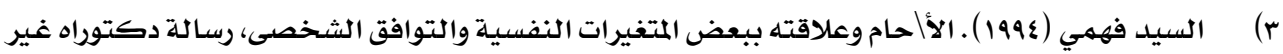

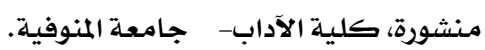

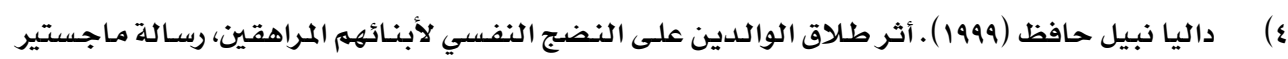

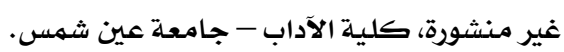

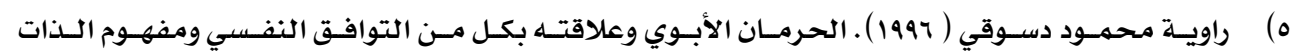

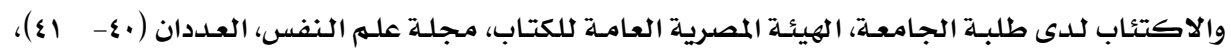

. -11

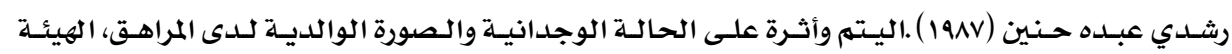

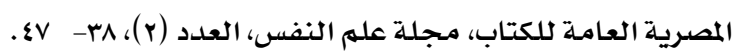

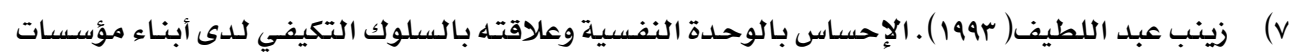

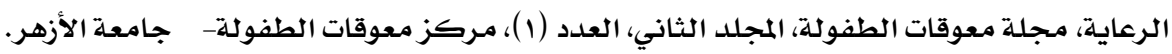

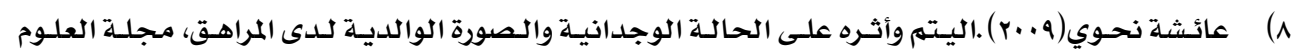

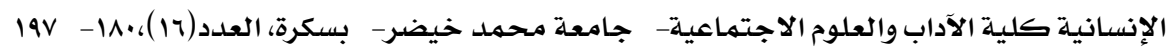

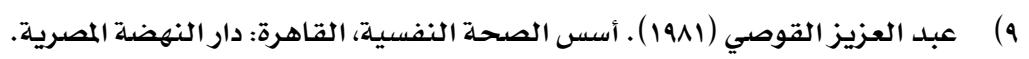

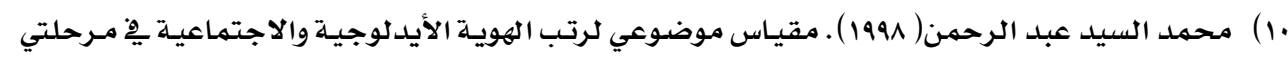

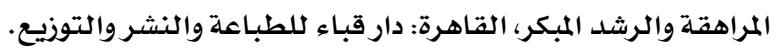




$$
\begin{aligned}
& \text { مجلة بحوث التربية النوعية - علد rr - أكتوبر r. r. }
\end{aligned}
$$

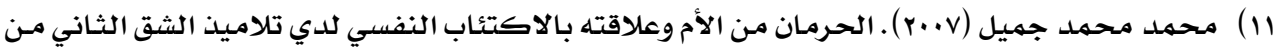

$$
\begin{aligned}
& \text { http://www.elssafa.com }
\end{aligned}
$$

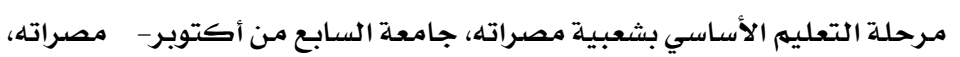

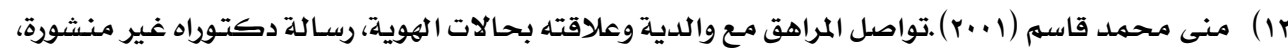

$$
\text { معهد الدراسـات والبحوث التربويـة، جامعة القاهرة. }
$$

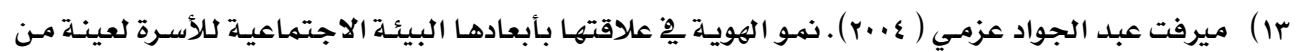

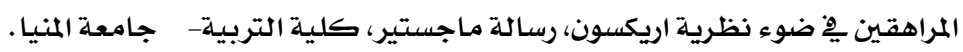

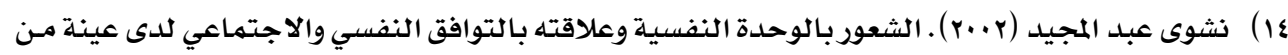

الأطفـال المحـرومـين وغير المحـرومـين مـن الرعايـة الأسـرية، رسـالة مـاجستير غير منـشورة، معهد الدراسـات

$$
\text { العليا للطفولة - جامعة عين شمس. }
$$

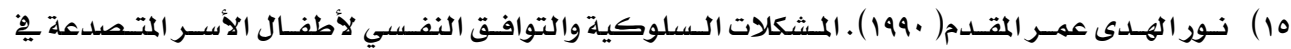

$$
\text { المرحلة الابتدائية، }
$$

www.gulfkids.com / pdf / mushklat- nafse

\section{ثانياً: المراجع الأجنبية:}

16- David L. Stevenson, David P. Baker. (1987). The Family- School Relation and the child's school performance, The society for research in Child Development, 58 (5), 1348- 1357.

17- Jersild, Arthur Thomas .(1957). The psychology of adolescence, New York : Macmillan.

18- Marcia J. E. (1966). Development and validation of ego identity status. Journal of Personality and Social Psychology, 3, 5: 551- 558. 